LA-14301

Approved for public release;

distribution is unlimited.

Small Mammal Sampling in Mortandad and

Los Alamos Canyons, 2005 
Edited by Hector Hinojosa, Group IRM-CAS

Los Alamos National Laboratory, an affirmative action/ equal opportunity employer, is operated by Los Alamos National Security, LLC, for the National Nuclear Security Administration of the U.S. Department of Energy under contract DE-AC52-06NA25396.

\section{INAS}

This report was prepared as an account of work sponsored by an agency of the U.S. Government. Neither Los Alamos National Security, LLC, the U.S. Government nor any agency thereof, nor any of their employees make any warranty, express or implied, or assume any legal liability or responsibility for the accuracy, completeness, or usefulness of any information, apparatus, product, or process disclosed, or represent that its use would not infringe privately owned rights. Reference herein to any specific commercial product, process, or service by trade name, trademark, manufacturer, or otherwise does not necessarily constitute or imply its endorsement, recommendation, or favoring by Los Alamos National, LLC, the U.S. Government, or any agency thereof. The views and opinions of authors expressed herein do not necessarily state or reflect those of Los Alamos National Security, LLC, the U.S. Government, or any agency thereof. Los Alamos National Laboratory strongly supports academic freedom and a researcher's right to publish; as an institution, however, the Laboratory does not endorse the viewpoint of a publication or guarantee its technical correctness. 
LA-14301

Issued: August 2006

Small Mammal Sampling in Mortandad and

Los Alamos Canyons, 2005

Kathy Bennett

Sherri Sherwood

Rhonda Robinson 



\section{Contents}

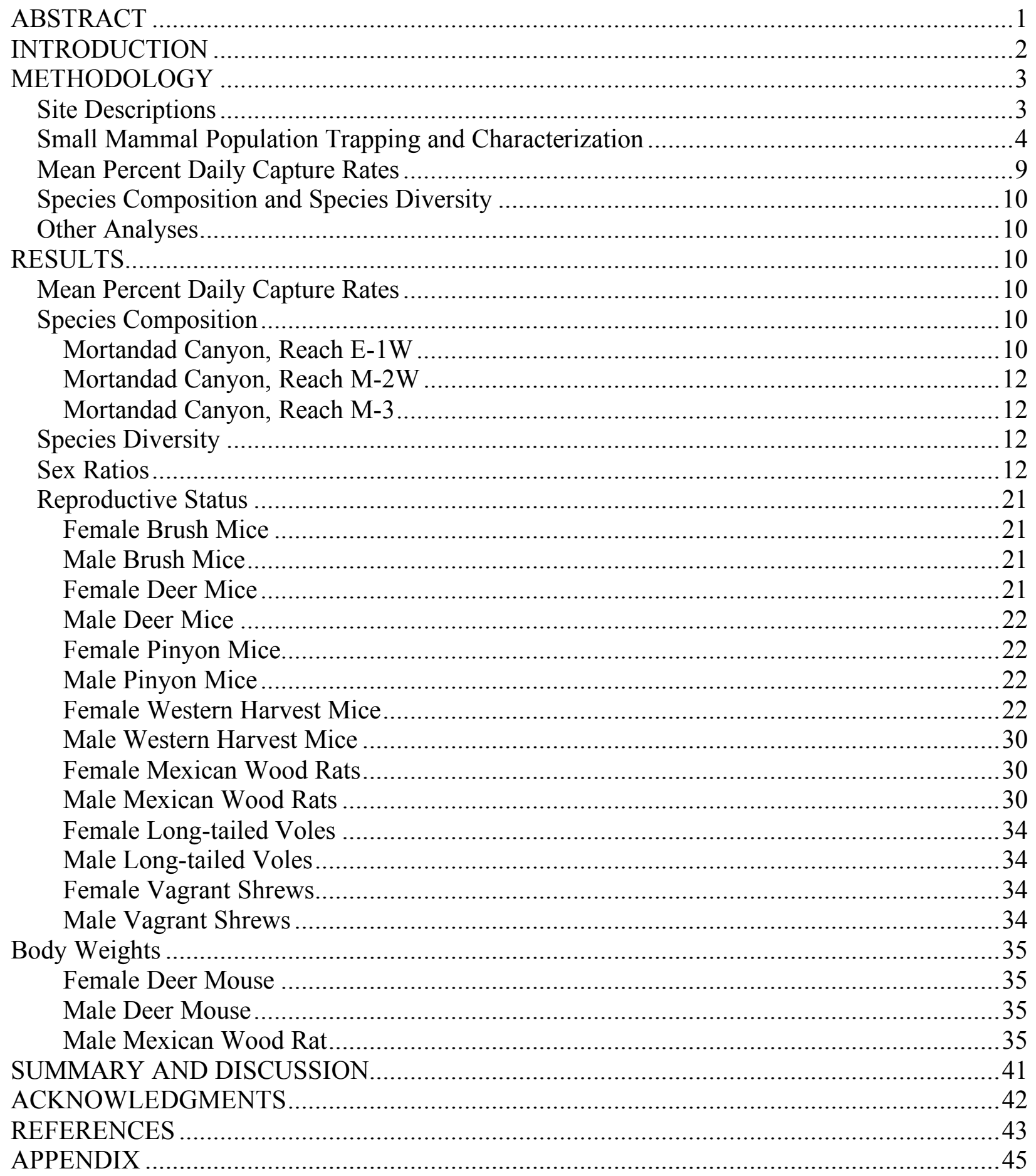




\section{List of Figures}

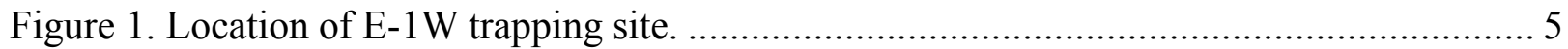

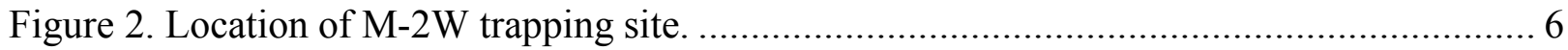

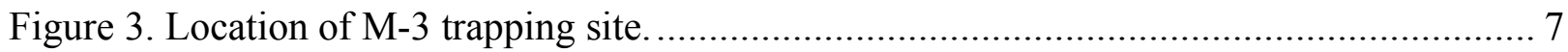

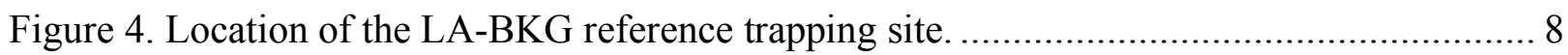

Figure 5. Mean percent daily capture rates for Mortandad Canyon sites and the Los Alamos Canyon background site.

Figure 6. The number of species captured in Mortandad, E-1W, and LA-BKG during summer sampling.

Figure 7. The number of species captured in Mortandad, M-2W, and LA-BKG during summer

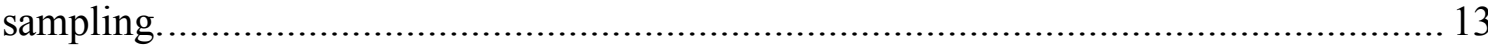

Figure 8. The number of species captured in Mortandad, M-3, and LA-BKG during summer sampling.

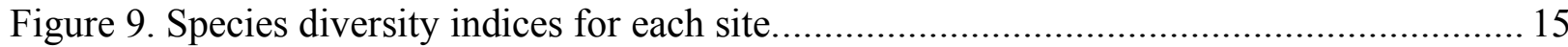

Figure 10. Males and females of each species captured in Mortandad Canyon, E-1W. .............. 17

Figure 11. Males and females of each species captured in Mortandad Canyon, M-2W. ............ 18

Figure 12. Males and females of each species captured in Mortandad Canyon, M-3 ................. 19

Figure 13. Males and females of each species captured in Los Alamos Canyon, LA-BKG. ….. 20

Figure 14. Reproductive status of female brush mice captured during summer sampling.......... 23

Figure 15. Reproductive status of male brush mice captured during summer sampling............. 24

Figure 16. Reproductive status of female deer mice captured during summer sampling............ 25

Figure 17. Reproductive status of male deer mice captured during summer sampling............... 26

Figure 18. Reproductive status of female pinyon mice captured during summer sampling........ 28

Figure 19. Reproductive status of female western harvest mice captured during summer

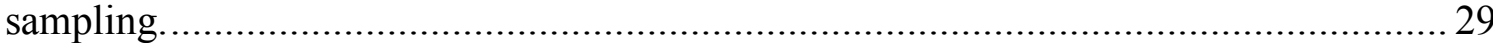

Figure 20. Reproductive status of male western harvest mice captured during the summer

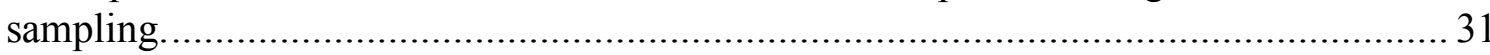

Figure 21. Reproductive status of female Mexican wood rats captured during summer sampling.

Figure 22. Reproductive status of male Mexican wood rats captured during summer sampling

Figure 23. Reproductive status of female long-tailed voles captured during summer sampling 36

Figure 24. Reproductive status of male long-tailed voles captured during summer sampling. ...3 37

Figure 25. Reproductive status of female vagrant shrews captured during summer sampling.... 38 
Figure 26. Mean, maximum, and minimum weights of adult female small mammals captured at the four trapping sites. ............................................................. 39

Figure 27. Mean, maximum, and minimum weights of adult male small mammals

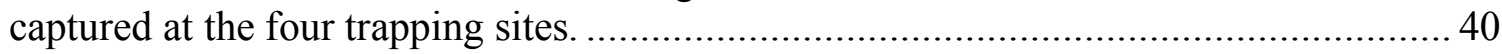

\section{List of Tables}

Table 1. Chi-square values and probability for testing the equal proportions of males to females of each species at each site.

Table 2. Number of male and female brush mice captured during the summer in all four sampling areas.

Table 3. Number of male and female deer mice captured during the summer in all four sampling areas.

Table 4. Number of male and female pinyon mice captured during the summer in all four sampling areas.

Table 5. Number of male and female western harvest mice captured during the summer in all four sampling areas.

Table 6. Number of male and female Mexican wood rats captured during the summer in all four sampling areas. 30

Table 7. Number of male and female long-tailed voles captured during the summer in all four sampling areas.

Table 8. Number of male and female vagrant shrews captured during the summer in all four sampling areas. 


\title{
Small Mammal Sampling in Mortandad and Los Alamos Canyons, 2005
}

by

\author{
Kathy Bennett, Sherri Sherwood, Rhonda Robinson
}

\begin{abstract}
As part of an ongoing ecological field investigation at Los Alamos National Laboratory, a study was conducted that compared measured contaminant concentrations in sediment to population parameters for small mammals in the Mortandad Canyon watershed. Mortandad Canyon and its tributary canyons have received contaminants from multiple solid waste management units and areas of concern since establishment of the Laboratory in the 1940s. The study included three reaches within Effluent and Mortandad canyons (E-1W, M-2W, and M-3) that had a spread in the concentrations of metals and radionuclides and included locations where polychlorinated biphenyls and perchlorate had been detected. A reference location, reach LA-BKG in upper Los Alamos Canyon, was also included in the study for comparison purposes. A small mammal study was initiated to assess whether potential adverse effects were evident in Mortandad Canyon due to the presence of contaminants, designated as contaminants of potential ecological concern, in the terrestrial media. Study sites, including the reference site, were sampled in late July/early August. Species diversity and the mean daily capture rate were the highest for E-1W reach and the lowest for the reference site. Species composition among the three reaches in Mortandad was similar with very little overlap with the reference canyon. Differences in species composition and diversity were most likely due to differences in habitat. Sex ratios, body weights, and reproductive status of small mammals were also evaluated. However, small sample sizes of some species within some sites affected the analysis. Ratios of males to females by species of each site $(n=5)$ were tested using a Chi-square analysis. No differences were detected. Where there was sufficient sample size, body weights of adult small mammals were compared between sites. No differences in body weights were found. Reproductive status of species appears to be similar across sites. However, sample size prevents a detailed examination of reproduction composition. Because of small sample size of some species and differences that might occur on a seasonal basis, additional sampling would need to be conducted to further evaluate sex ratios, body weights, and reproductive characteristics.
\end{abstract}




\section{INTRODUCTION}

Mortandad Canyon and its tributary canyons have received contaminants from multiple solid waste management units and areas of concern at Los Alamos National Laboratory (LANL) since establishment of the Laboratory in the 1940s (LANL 2005). This watershed also receives discharges from several National Pollutant Discharge Elimination System (NPDES)-permitted outfalls. The Mortandad Canyon watershed has been the subject of a number of investigations that indicate that soil, sediment, and surface water contain contaminants that may pose a risk to ecological receptors. The purpose of this investigation was to evaluate the potential adverse impacts to small mammals from contaminants in Mortandad Canyon and its tributaries in support of a broader investigation of potential ecological risks in the watershed as outlined in the Mortandad Canyon Biota Investigation Work Plan (LANL 2005).

A small mammal study was initiated to assess whether potential adverse effects were evident in Mortandad Canyon due to the presence of contaminants, designated as contaminants of potential ecological concern (COPECs), in the terrestrial media (LANL 2005). Los Alamos Canyon was selected as a reference canyon because of its similar topographical characteristics and absence of known contaminant sources (LANL 2005). Small mammals have been frequently used to monitor the presence of contaminants and have been found to be effective biomonitors. The objectives of the small mammal investigation were to obtain population parameters such as relative abundance and sex ratios to evaluate the risk to the species themselves and to higher trophic level predators, such as the Mexican spotted owl (Strix occidentalis lucida), a federally protected species known to occur within the Mortandad watershed. Determining population characteristics of small mammals will aid in identifying potential contaminant loads and transport routes of contaminants through the ecosystem (Bennett et al., 1996). Small mammals typically include ground-dwelling species within a body weight range of 6 to $900 \mathrm{~g}$. Small mammals typically captured in the area of the Mortandad watershed include mice from the genera Peromyscus (including deer mouse [Peromyscus maniculatus-PEMA], brush mouse [Peromyscus boylii-PEBO], and pinyon mouse [Peromyscus truei-PETR]), long-tailed voles (Microtus longicaudus-MILO), vagrant shrews (Sorex vagrans-SOVA), Mexican wood rats (Neotoma mexicana-NEME), and western harvest mice (Reithrodontomys megalotis-REME). These species have short life spans (less than one year) and occupy small home ranges ( $\sim 100$ $\mathrm{m}^{2}$ ). They are easy to capture and, depending on habitat and environmental conditions, are 
generally abundant (Talmage 1989). All of these species are considered suitable prey for the Mexican spotted owl.

The watershed was divided into a number of reaches that were sampled based on their proximity to potential sources of contamination to the canyon (LANL 2005, Figure 1.0-1, p. 23). A screening level ecological risk assessment was then conducted for these reaches (LANL 2005, Appendix B). Three areas in the Mortandad Canyon watershed were selected as small mammal trapping sites based on the results of the screening evaluations: E-1W, M-2W, and M-3. Several considerations figured into the selection of the reaches. Those with high and, alternately, low concentrations of COPECs were selected to provide a range of COPEC exposure concentrations for contaminant analyses. Prior investigations determined that $\mathrm{M}-2 \mathrm{~W}$ might contain high levels of perchlorate and M-3 might contain low concentrations of perchlorate. All three reaches represent potential Mexican spotted owl habitat and included COPECs in sediment for the spotted owl (Aroclor-1254) and mammalian insectivores (arsenic, manganese, and thallium).

\section{METHODOLOGY}

Trapping grids were set up in the Mortandad Canyon watershed in three reaches, E- $1 \mathrm{~W}, \mathrm{M}-2 \mathrm{~W}$, and M-3, during July and August 2005. Los Alamos Canyon reach LA-BKG was selected as the reference site due to similarities in topography, elevation, presence of water, vegetation, and lack of contaminants. The same trapping system used in Cañon de Valle (LANL 2003) and Pueblo and Los Alamos canyons (Robinson and Bennett 2002; LANL 2004) were utilized in this study.

\section{Site Descriptions}

LANL is situated in northern New Mexico on the Pajarito Plateau, a series of finger-like mesas separated by east-to-west-oriented canyons. The mesa tops slope from approximately $2377 \mathrm{~m}$ $(7800 \mathrm{ft})$ to $1890 \mathrm{~m}(6200 \mathrm{ft})$. The surrounding land is largely undeveloped, including large tracts held by the Santa Fe National Forest, Bureau of Land Management, Bandelier National Monument, and San Ildefonso Pueblo. Consequently, well-developed ecosystems that include habitat for four federally protected species exist within the undeveloped areas of LANL. This is particularly true of the canyon bottoms, some of which contain either ephemeral or perennial reaches of surface water.

Mortandad Canyon heads at an elevation of approximately $2260 \mathrm{~m}(7420 \mathrm{ft})$ in the western part of the Pajarito Plateau and has a drainage area of $1.8 \mathrm{mi}^{2}$ west of the boundary between the 
Laboratory and San Ildefonso Pueblo. Surface flow is entirely ephemeral except for some reaches supplied by effluent releases. Mortandad Canyon is currently the primary release area for treated radioactive effluents at the Laboratory (Gallaher et al., 1997). Major tributaries to Mortandad Canyon in the study area are, from east to west, Effluent Canyon, Ten Site Canyon, and an unnamed tributary that includes the Mortandad Canyon watershed reaches. Vegetation communities in the watershed include forest (predominantly Pinus ponderosa, Pseudotsuga menziesii, and Abies concolor), juniper (Juniperus monosperma) woodland, grassland (primarily Bromus tectorum, Eragrostis stolonifera, and Oryzopsis micranta), and shrubland (Quercus gambelii, Salix exigua, Rhus trilobata, and Ribes cereum) (Balice and Sandoval 2006). Riparian and wetland communities occur along the stream channels in areas receiving effluent discharges. Two of the reaches in the study area, E-1W and M-2W, had surface water during each site visit. Both of these receive effluent discharges from NPDES outfalls. The most extensive area of cattail wetlands occurs in reach E-1W.

Reach LA-BKG in Los Alamos Canyon is characterized by steep slopes and a canyon bottom measuring approximately $116 \mathrm{~m}$ ( $383 \mathrm{ft}$ ) wide. Elevation of the canyon bottom ranges from 2267 $\mathrm{m}(7481 \mathrm{ft})$ to $2287 \mathrm{~m}$ (7547 ft). The site is dominated by an overstory of Pinus ponderosa, Populus tremuloides, Betula occidentalis, and Picea engelmannii. A wide variety of shrubs (predominantly Rubus parviflorus, Ribes inerme, Jamesia americana, Sambucus microbotrys, Lonicera involucrate, and Quercus gambelii) and forbs (primarily Equisetum hiemale, Senecio wootonii, Pterdium aquilinum, Geranium richardsonii, and Rudbeckia lacinata) also occur on the site. Grasses include Bromus spp. and Carex occidentalis. The stream channel parallels the southwest boundary of the study site. The National Wetlands Inventory has characterized this stream channel as riverine, intermittent, streambed, and temporarily flooded (Robinson and Bennett 2002). The stream was actively flowing during the trapping session.

\section{Small Mammal Population Trapping and Characterization}

Generally, the study utilized grids of 100 traps. Based on the topography of each trapping location within each reach, two to five grid lines consisting of 20 or more Sherman live traps, placed at 10-m intervals, were used (see the Appendix). However, the Effluent Canyon reach E$1 \mathrm{~W}$ only had 10 traps per line and only three trap lines were used. Trap configuration at E-1W was modified to reflect the spatial extent of the reach. Figures 1 through 4 show the locations of the trapping sites within each reach and a background location, reach LA-BKG, within Los 


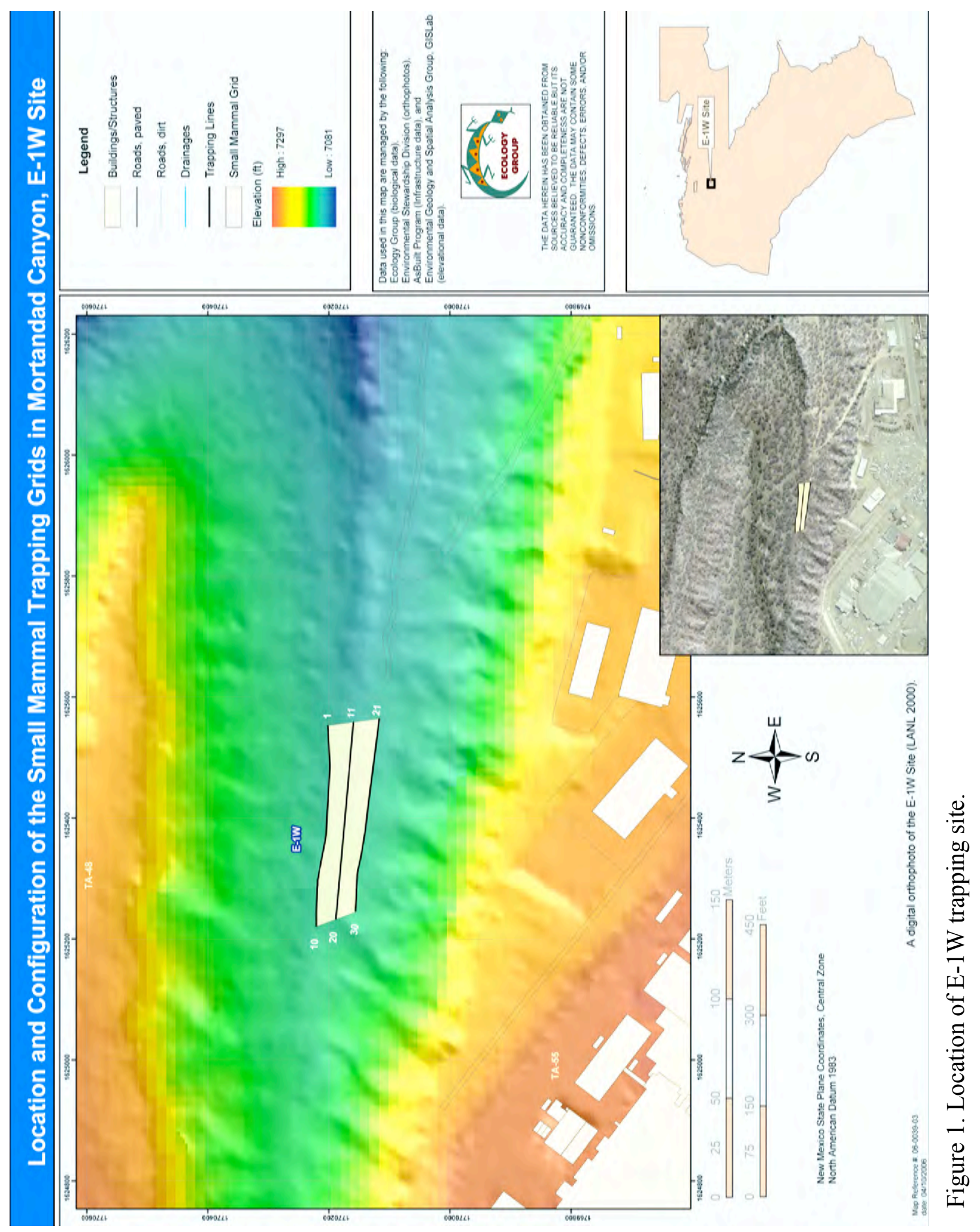



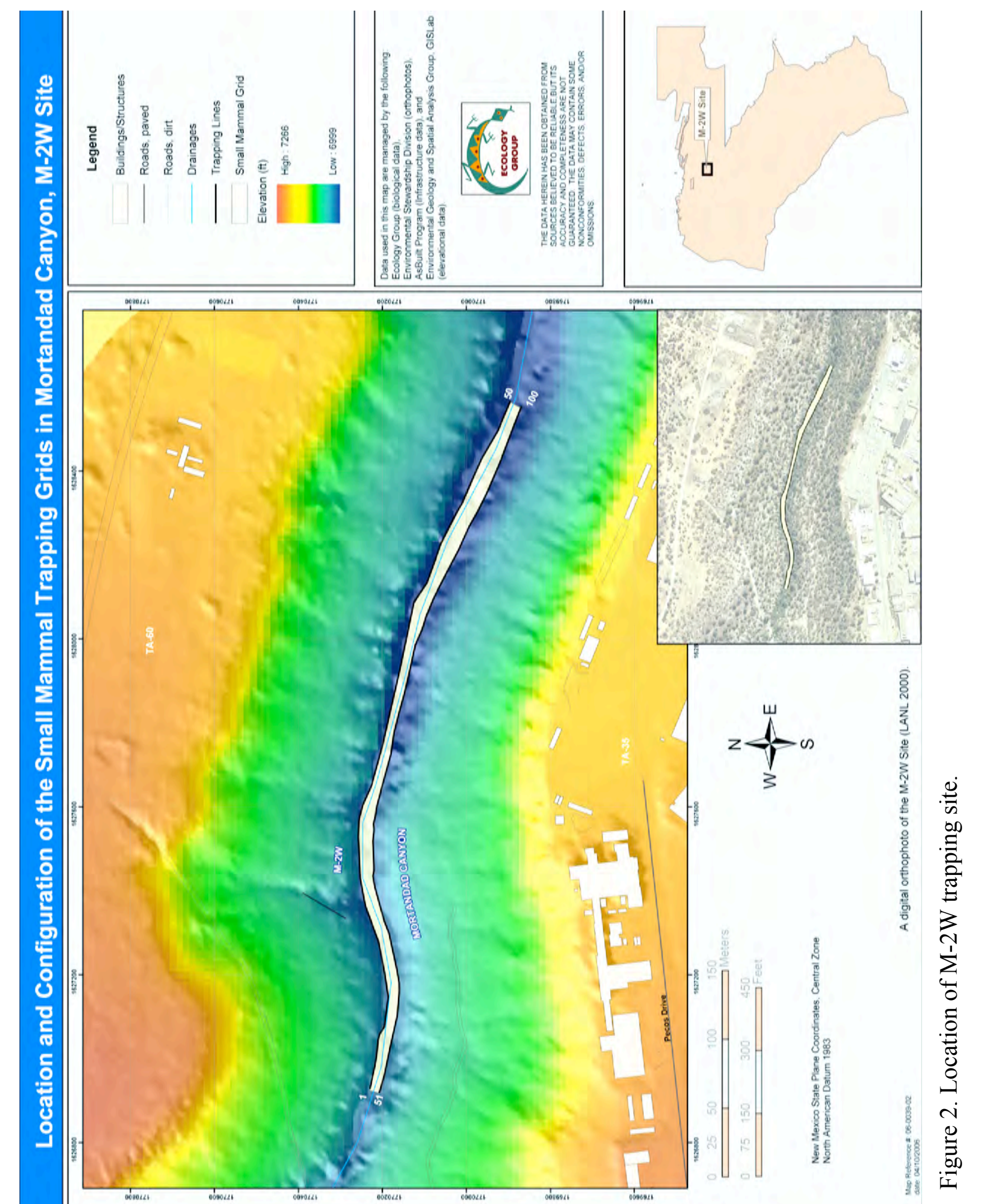


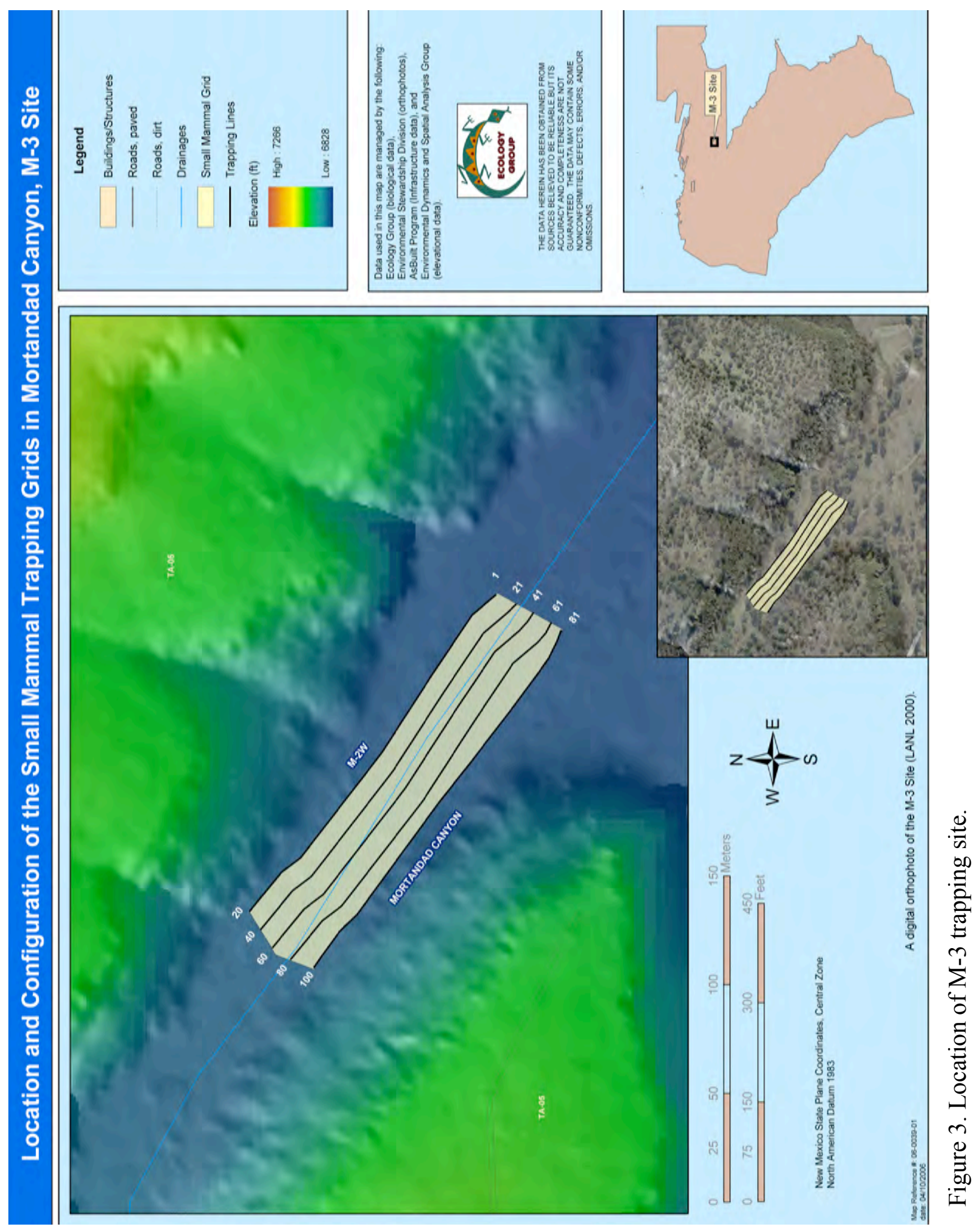




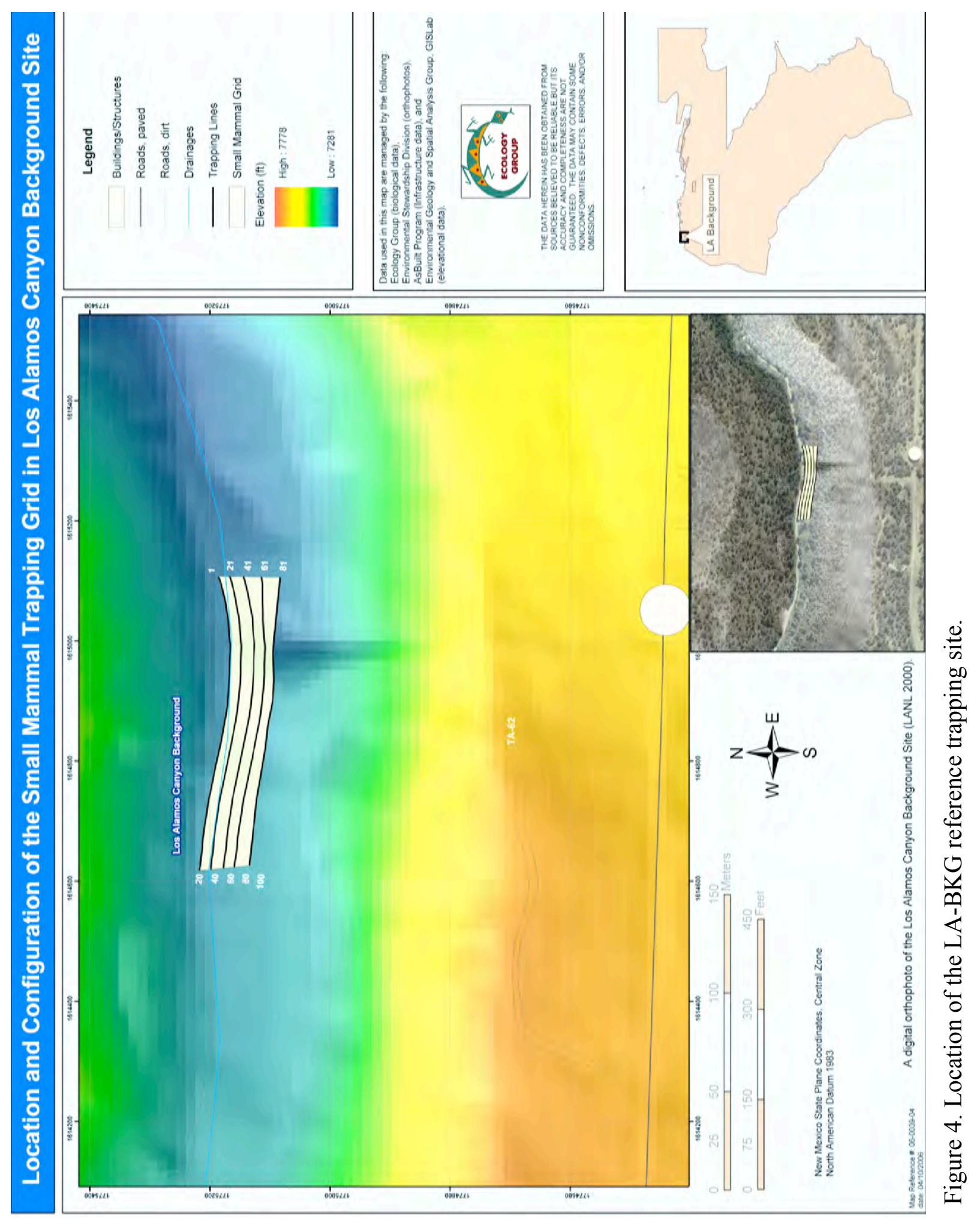


Alamos Canyon. Sherman live traps were selected because of their suitability for capturing the target species. Trap lines followed the contours of the land, with the stream channel as the reference point. Pitfall trap lines were placed parallel to the stream channels in E-1W and LABKG for shrew sampling. The pitfall traps consisted of buckets $24 \mathrm{~cm}$ in diameter and $20 \mathrm{~cm}$ deep, sunken flush with the soil, and each trap line had 10 traps with the exception of one in LA$\mathrm{BKG}$, which had only five pitfall traps. Trapping sessions extended over a period of four consecutive nights. Traps were baited each afternoon with a mixture of peanut butter and sweet feed (molasses-coated horse feed). Traps were checked early each morning and those that had been tripped were collected and those that were not were closed for the day. Traps with animals were taken to a central processing station where they were identified to species, sexed, weighed, and measured (total body, tail, hind foot, and ear length). Reproductive status and trap number were recorded as well. Animals were then euthanized and the pelts were removed (Bennett et al., 1996). Precautions during handling were taken to minimize cross contamination from carcass to

pelt while removing pelts. All external hair was removed from the appendages. If the sample size had been met for a particular species, those animals were processed, ear-tagged, and released. If these animals were recaptured, only the ear tag number and trap number were recorded. The minimum number of samples required for statistical analysis for polychlorinated biphenyls, pesticides, and metals was six animals of each species per location. A sample size of six was necessary to meet the minimum power for the detection of median shifts. However, in some sampling areas, six animals/species were not obtained.

Since the target species are known to be potential carriers of Hantavirus, all animals captured were screened prior to submittal for analyses. Blood samples taken from the interorbital region of all species, with the exception of shrews, were sent to the Medical School at the University of New Mexico for Hantavirus screening. Animals that tested negative for Hantavirus were used for contaminant analyses.

\section{Mean Percent Daily Capture Rates}

Population density estimates were not calculated for this study because of design requirements. However, mean percent daily capture rates were calculated. The mean was derived from the total number of available trap stations at each location, the number of trap nights, and the total number of animals captured. 


\section{Species Composition and Species Diversity}

Species composition and species diversity were determined for each site. Species composition represents the frequency of each species captured at each site. Species diversity is a measure of species variety and their proportions. Species diversity was calculated using the ShannonWeaver method (Hair 1980) and was based on capturing the seven different species (deer mouse, brush mouse, pinyon mouse, harvest mouse, Mexican wood rat, long-tailed vole, and vagrant shrew) we encountered in this study.

\section{Other Analyses}

Additional analyses were conducted to compare population characteristics of the sites.

Differences in sex ratios, reproductive stages, and mean body weights were evaluated.

A Chi-square analysis was used to look at differences between sex ratios of species in each study site (Zar 1984; SAS 1988). An assumption of equal proportional distribution of males to females was made for the Chi-square analysis. In order to utilize a Chi-square analysis, sufficient sample size of five or more samples in each group was needed. An alpha level of 0.05 was used.

A parametric analysis of variance $(\mathrm{AOV})$ was used to look at differences $($ alpha $=0.05)$ in adult weights by study site. Because the sample sizes were not balanced among the study sites, general linear model (GLM) was used to conduct the AOV (SAS 1988; Zar 1984; Beitinger 1988). A Tukey Multiple Range Test (MRT) was used to detect where the differences occurred and was selected because of its ability to handle an uneven design and the likelihood of less Type 1 errors compared to other MRTs (Zar 1984).

\section{RESULTS}

\section{Mean Percent Daily Capture Rates}

Mean percent daily capture rates were calculated for all of the Mortandad Canyon trapping sites and the Los Alamos Canyon background site (Figure 5). E-1W had the highest mean capture rate of $21.67 \%$, and LA-BKG had the lowest capture rate of 6.75\%. In Mortandad Canyon, capture rates decreased downstream, being lowest in M-3.

\section{Species Composition}

\section{Mortandad Canyon, Reach E-1W}

Eleven deer mice were captured in E-1W compared to the 19 deer mice that were captured at the reference site LA-BKG. One pinyon mouse was captured in E-1W and two were captured in LA- 


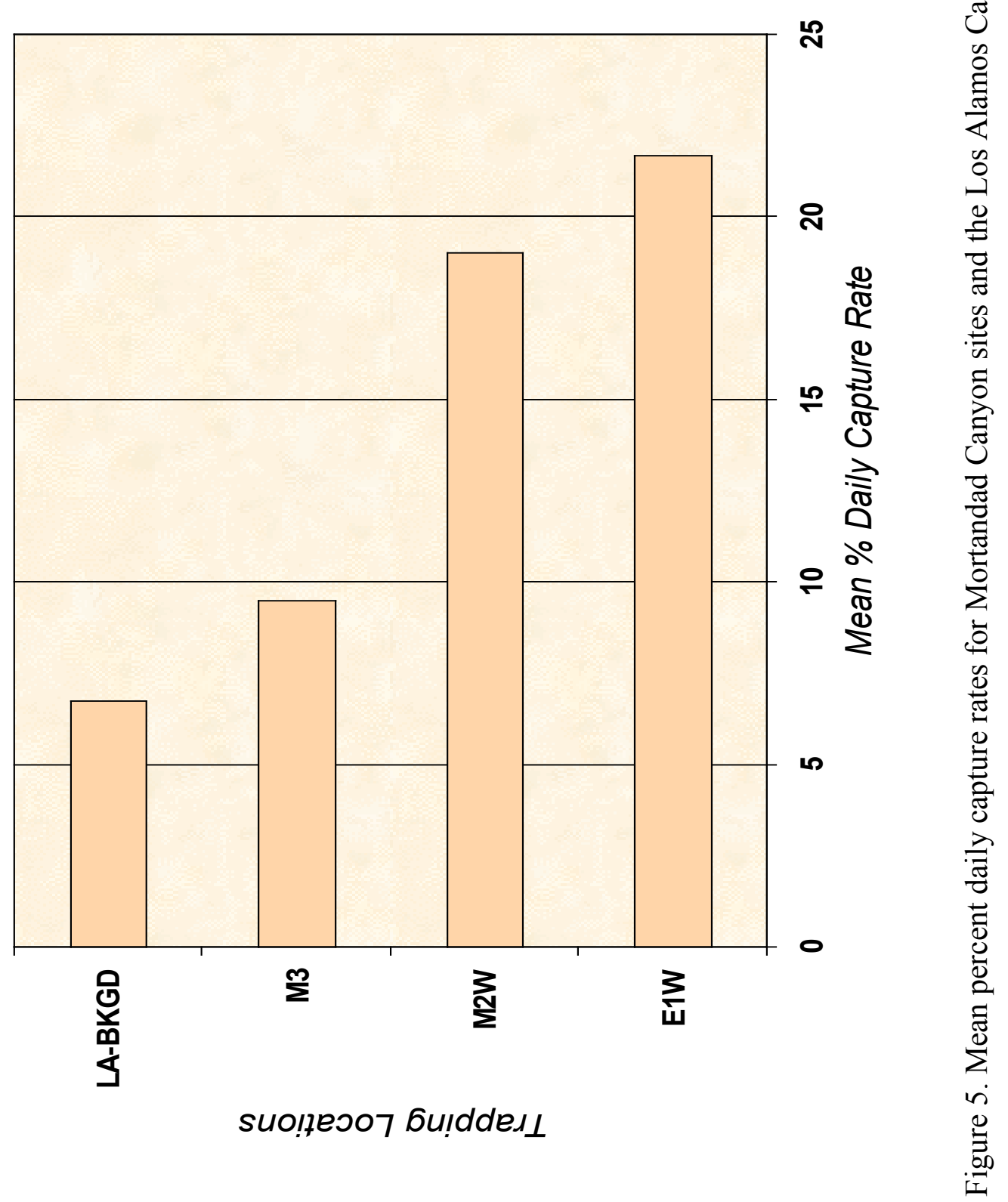


BKG. Two long-tailed voles were captured in E-1W and five were captured in LA-BKG. Two vagrant shrews were captured in E-1W, whereas only one was captured in LA-BKG. Mexican wood rat $(n=2)$, brush mouse $(n=7)$, and western harvest mouse $(n=1)$ were captured only in E-1W (Figure 6).

\section{Mortandad Canyon, Reach M-2W}

Approximately half as many deer mice were captured in M-2W $(n=10)$ compared to LA-BKG $(n=19)$. Mexican wood rat $(n=14)$ and brush mouse $(n=32)$ were captured only in M-2W. Long-tailed vole $(n=5)$ and vagrant shrew $(n=1)$ were captured only in the reference canyon (Figure 7).

\section{Mortandad Canyon, Reach M-3}

Deer mice, the only species shared by both trapping areas, were captured in similar numbers in M-3 $(\mathrm{n}=23)$ and LA-BKG $(\mathrm{n}=19)$. Mexican wood rat $(\mathrm{n}=5)$ and western harvest mouse $(n=10)$ were captured only in M-3, whereas pinyon mice $(n=2)$, long-tailed voles $(n=5)$, and vagrant shrews $(\mathrm{n}=1)$ were captured exclusively in LA-BKG (Figure 8).

\section{Species Diversity}

A species diversity index was calculated for each trapping site (Figure 9). E-1W had the highest index (2.25) and Los Alamos Canyon had the lowest index (1.267). Based on capturing seven different species per canyon, the maximum theoretical species diversity index was 2.807 .

\section{Sex Ratios}

Sex ratios of adult males to females trapped within the same reach and of the same species were compared using a Chi-square analysis with an assumption of an equal distribution between the two sexes (Table 1). Deer mouse was the only species with adequate sample size to be evaluated within all trapping sites. Brush mouse and Mexican wood rat were also evaluated for reach M2W only. Other sites and species did not have sufficient sample size for Chi-square analysis ( $\mathrm{n} \geq$ 5 in each group). There were no statistical differences found between the sex ratios of male and female small mammals that were analyzed. The frequency of males and females of each species are shown in Figures 10-13. 


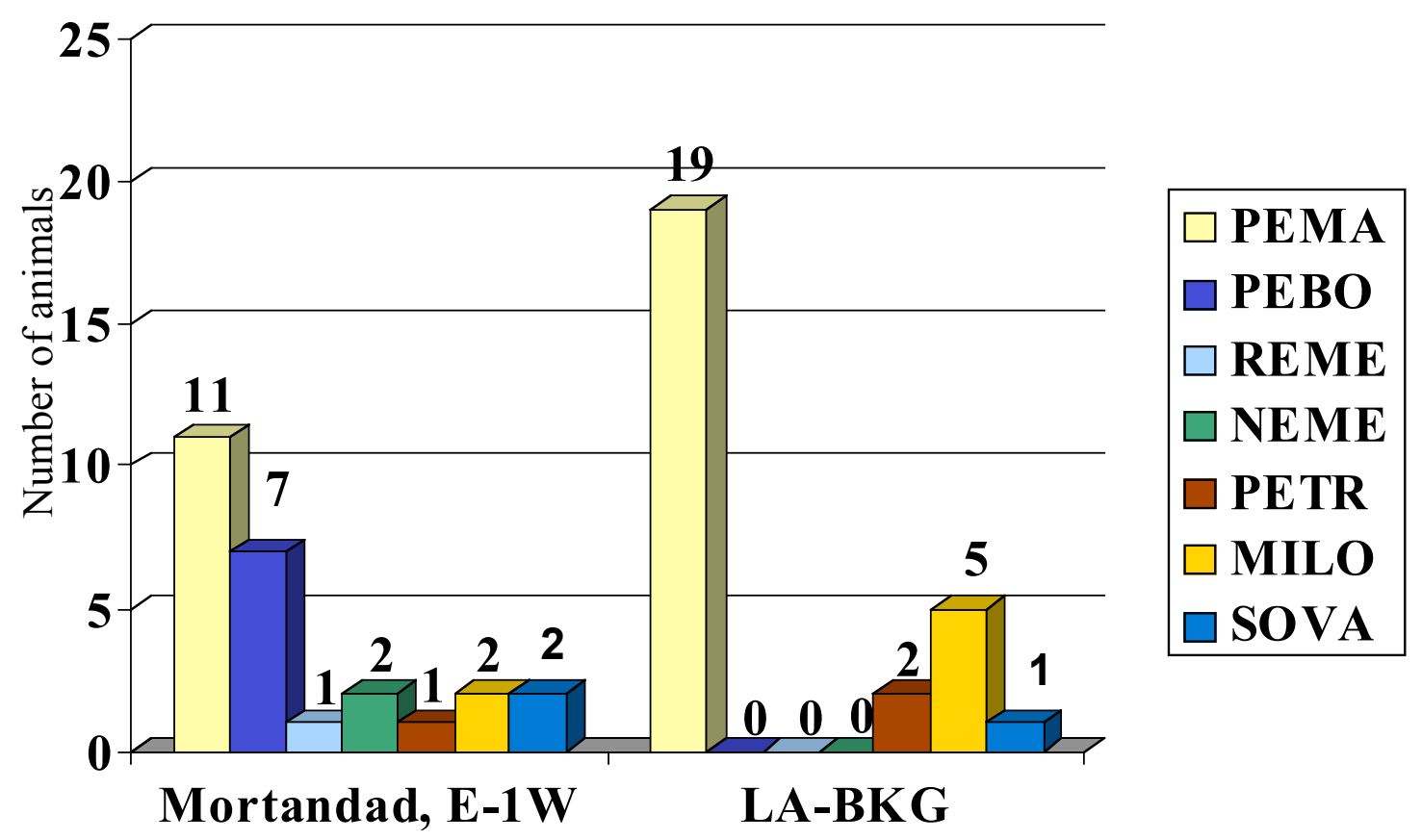

Figure 6. The number of species captured in Mortandad, E-1W, and LA-BKG during summer sampling.

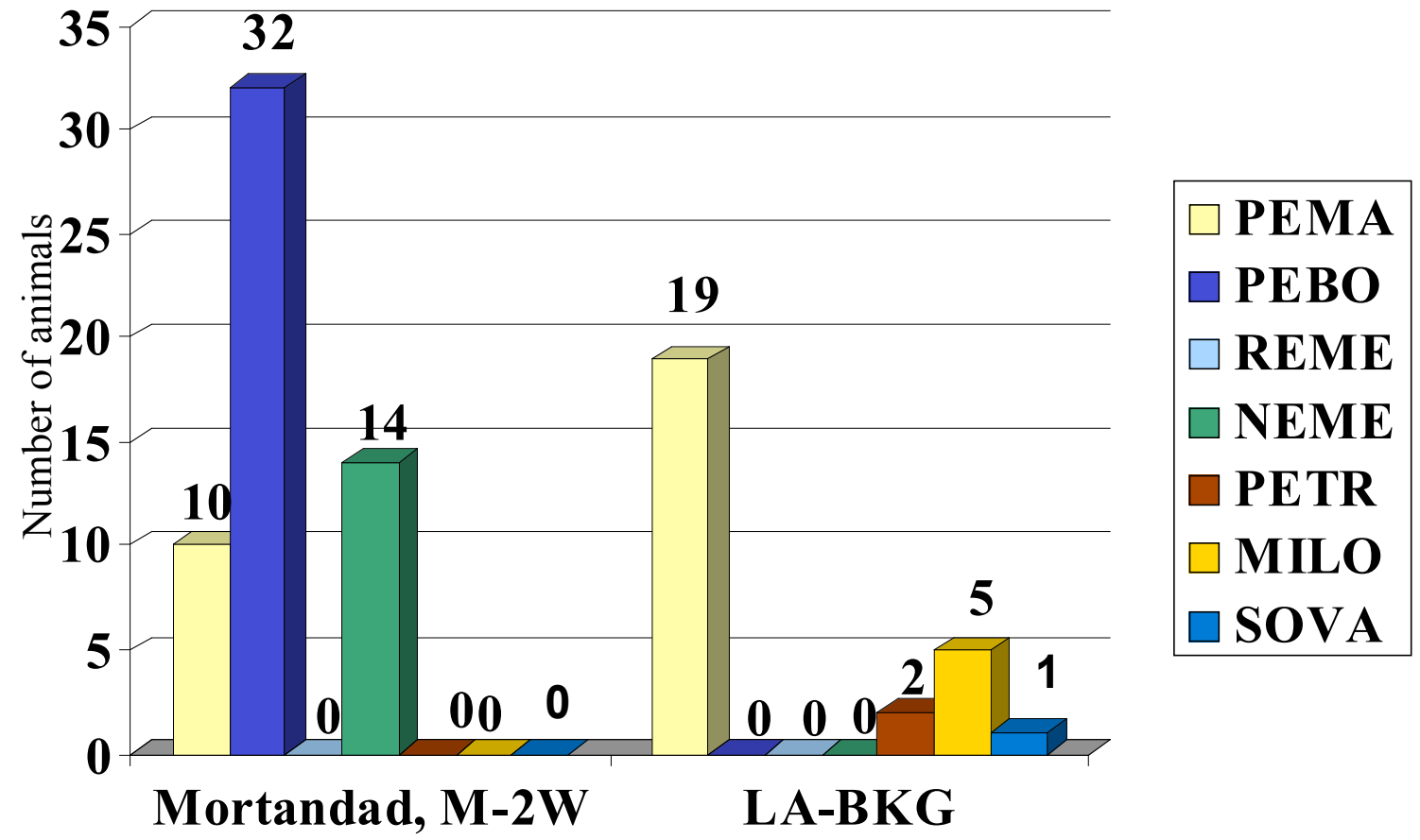

Figure 7. The number of species captured in Mortandad, M-2W, and LA-BKG during summer sampling. 


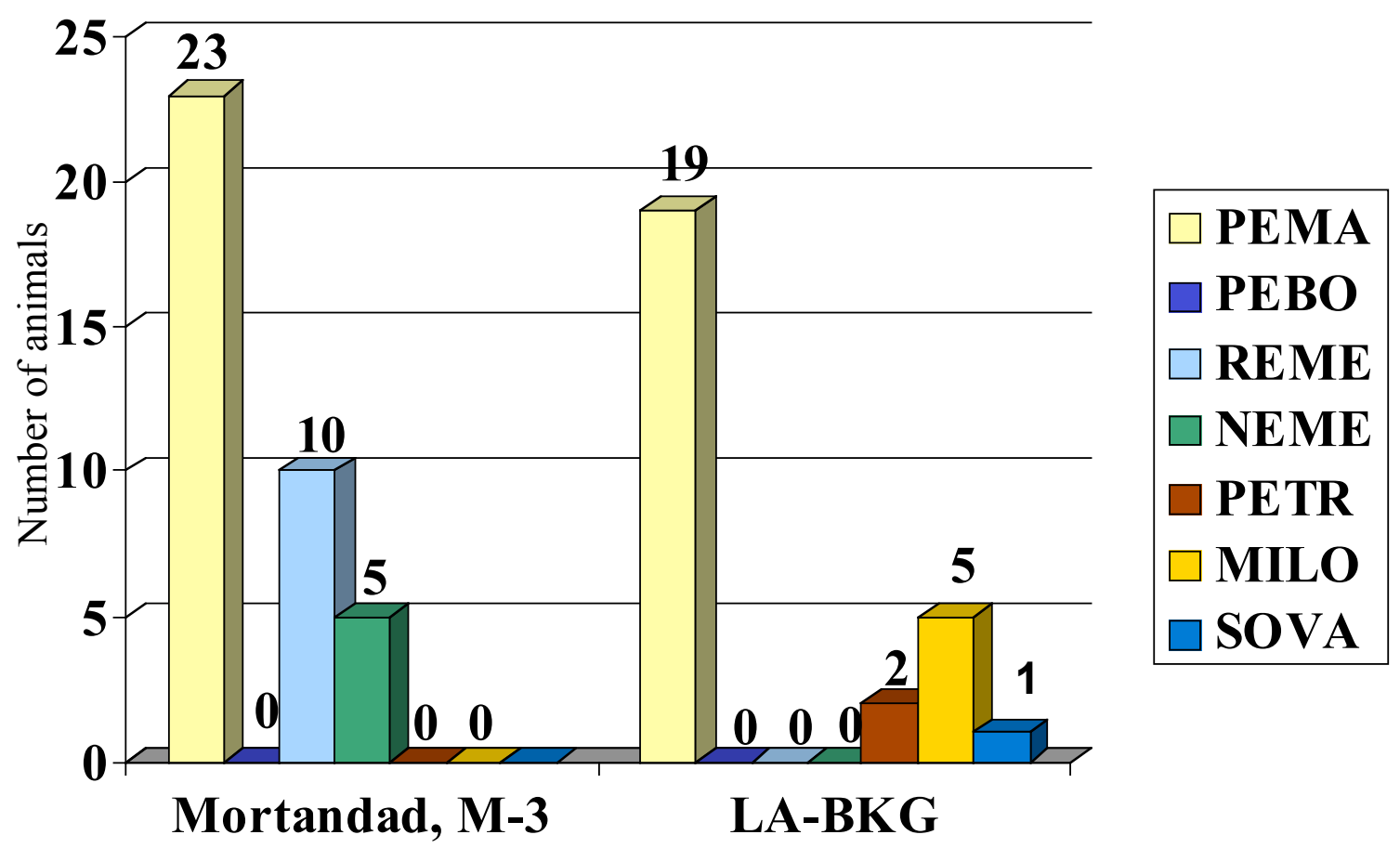

Figure 8. The number of species captured in Mortandad, M-3, and LA-BKG during summer sampling. 


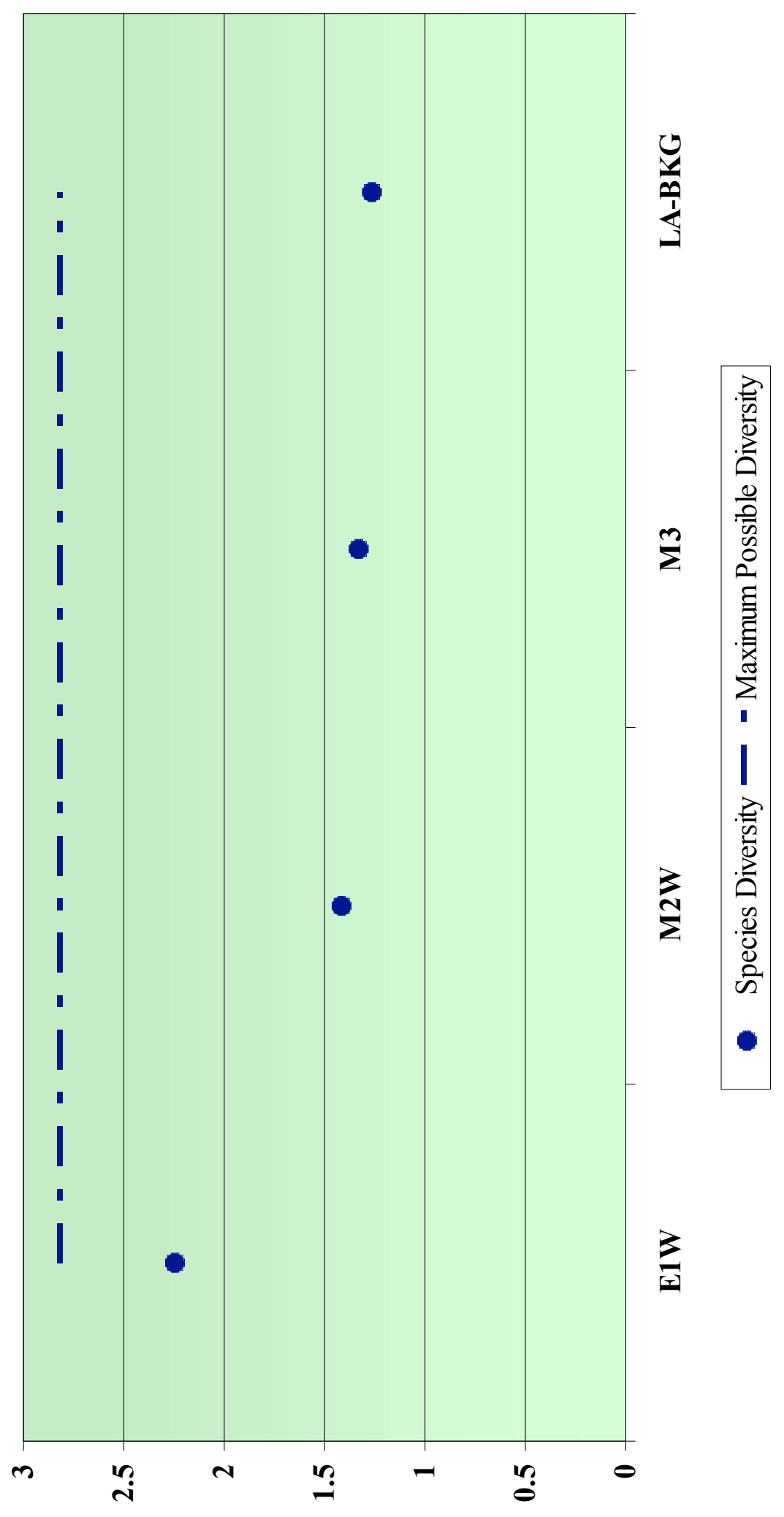

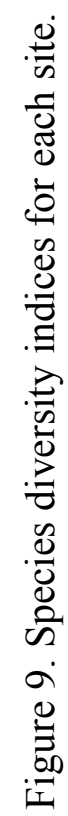




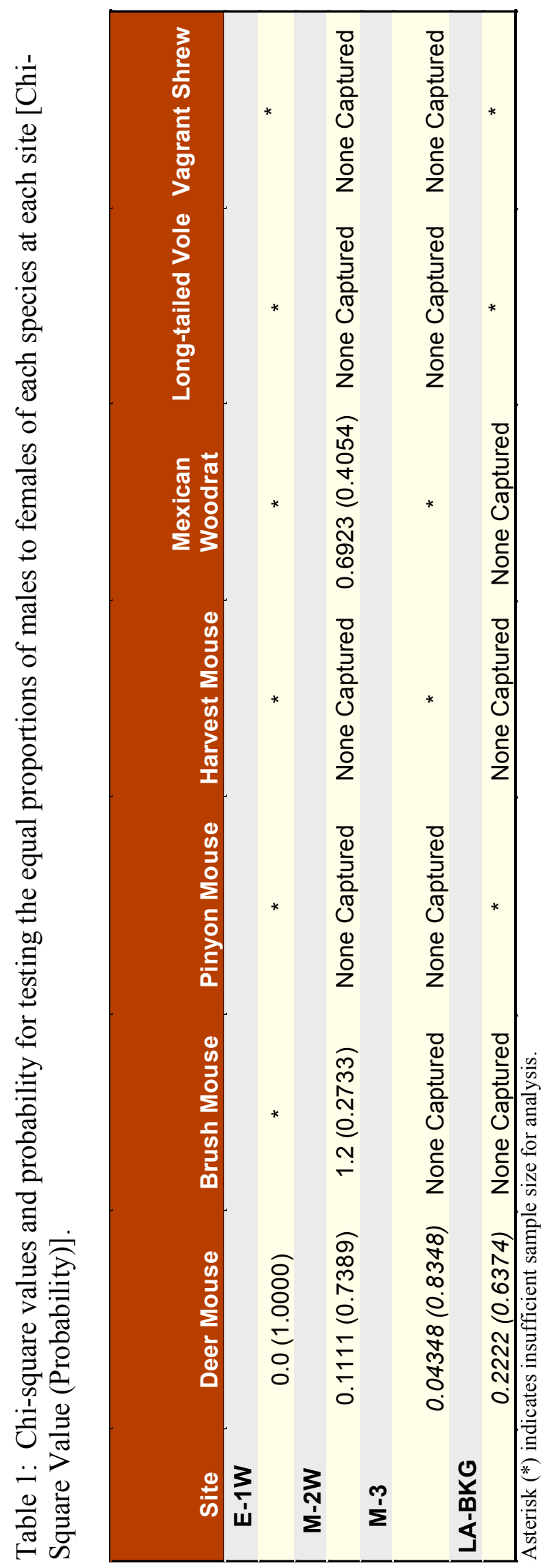




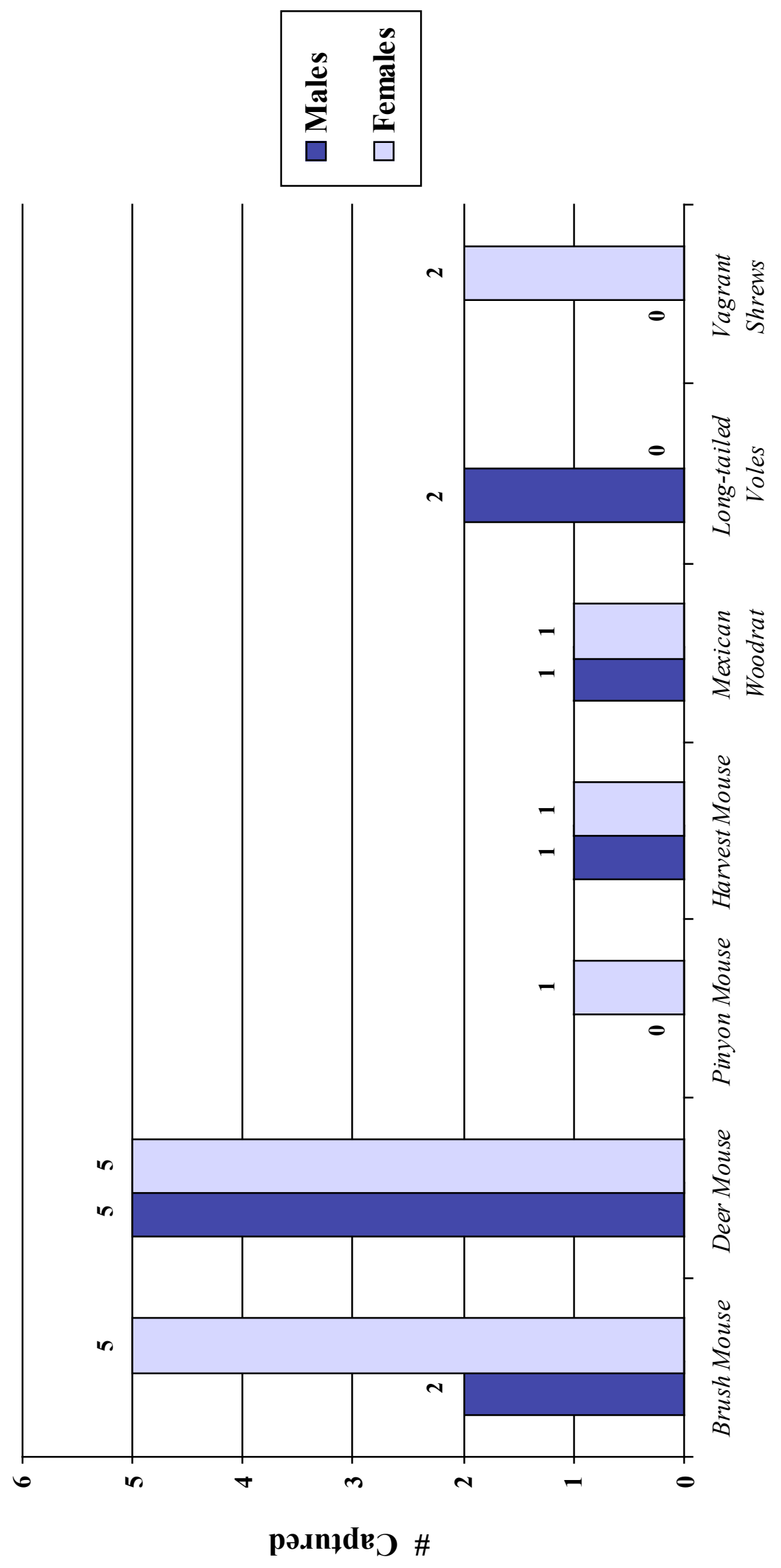

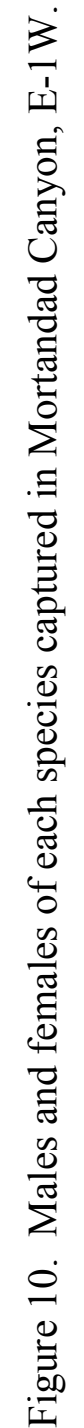




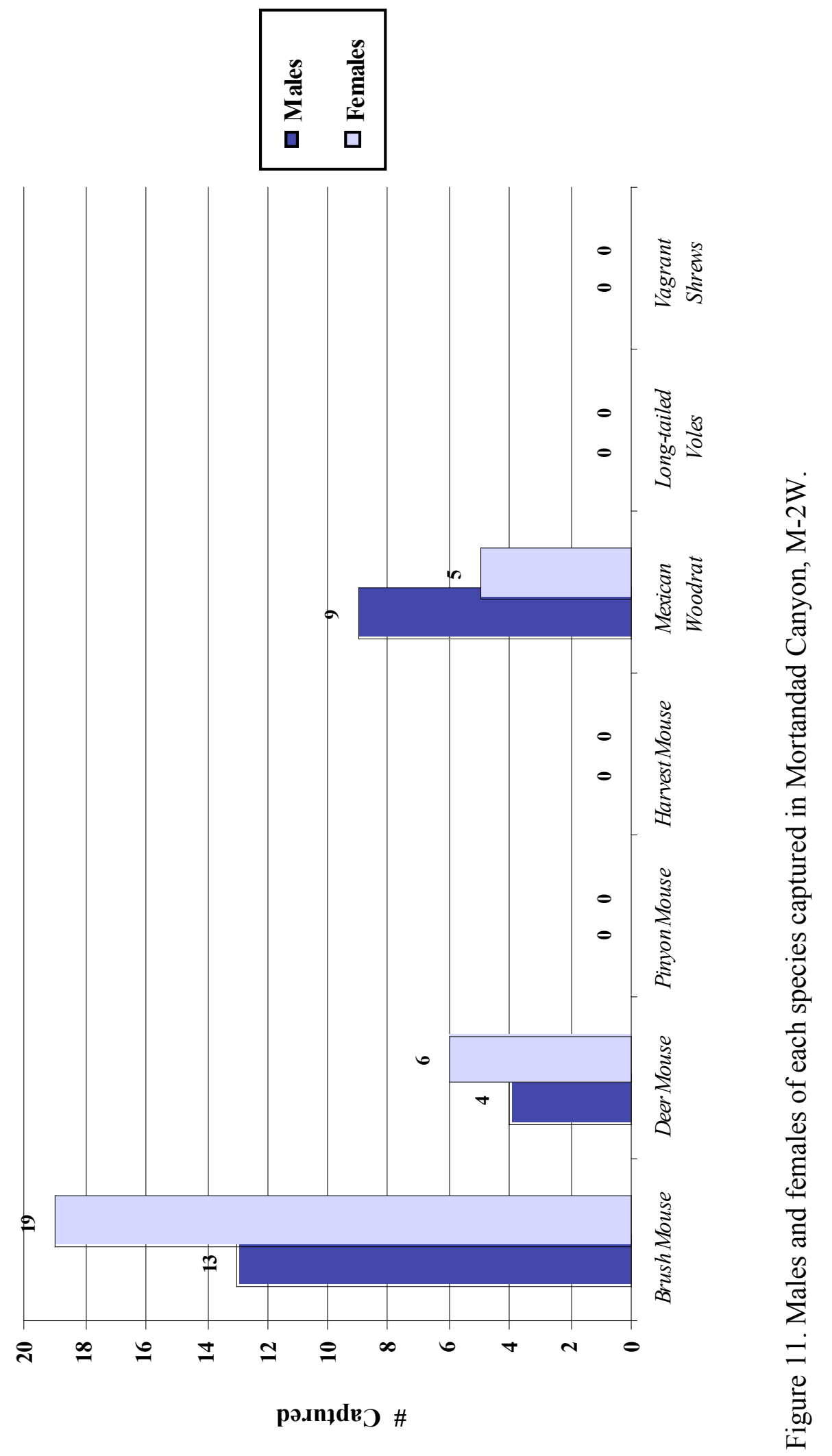




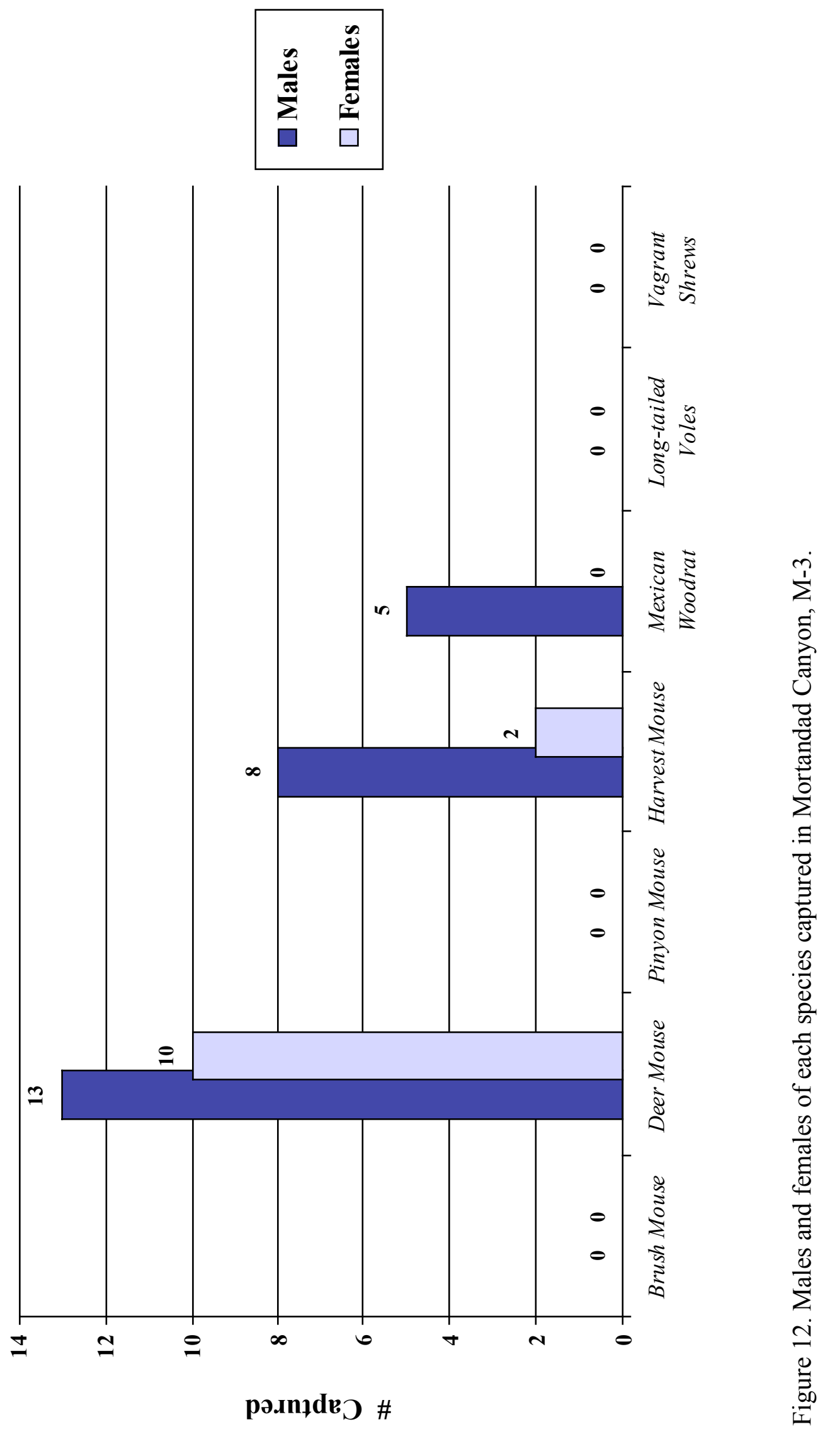




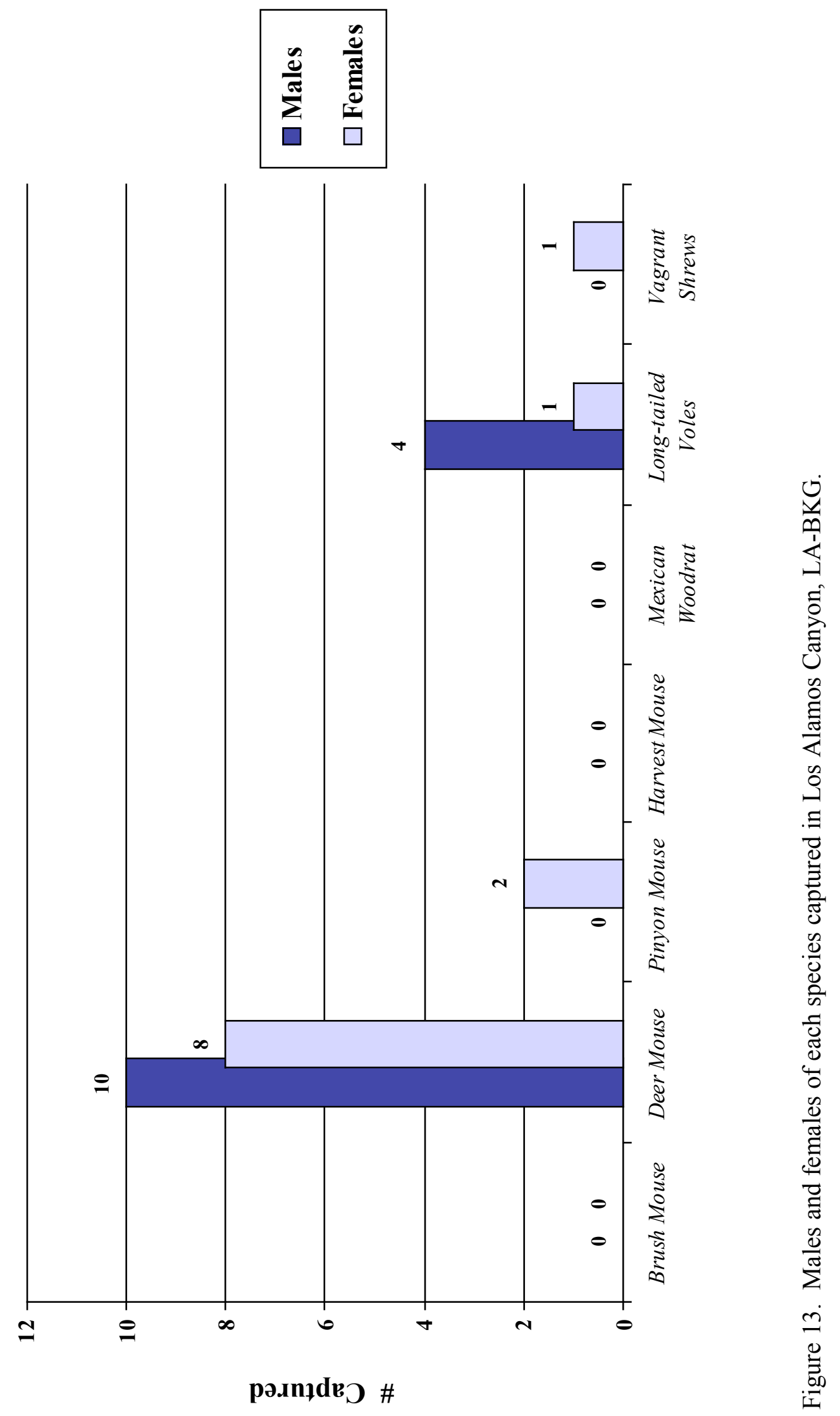




\section{Reproductive Status}

\section{Female Brush Mice}

Of the four reproductive categories (juvenile, non-reproductive, pregnant, and lactating) of female brush mice, three were represented in M-2W. Non-reproductive females $(n=13)$, pregnant $(n=5)$, and lactating $(n=1)$ were captured in $M-2 W$. Non-reproductive females were the only category represented in E-1W $(n=4)$. Female brush mice were not collected from M-3 or LA-BKG (Table 2 and Figure 14).

\section{Male Brush Mice}

Male brush mice were not collected from M-3 or LA-BKG. Non-scrotal male brush mice were captured in E-1W $(n=2)$ and M-2W $(n=9)$. Scrotal males were found only in M-2W $(n=4)$. Juveniles were not captured in either of these sampling areas (Table 2 and Figure 15).

\section{Female Deer Mice}

Similar numbers of non-reproductive female deer mice were captured in all four sampling areas, E-1W $(n=5), M-2 W(n=5), M-3(n=5)$, and LA-BKG $(n=5)$. This was the only category captured in E-1W. Lactating females were captured in M-2W (n=1), M-3 (n=3), and LA-BKG $(n=1)$. Equal numbers of pregnant females $(n=2)$ were captured in M-3 and LA-BKG (Table 3 and Figure 16).

Table 2. Number of male and female brush mice captured during the summer in all four sampling areas.

\begin{tabular}{|l|c|c|c|c|}
\hline \multicolumn{1}{|c|}{ Males } & E-1W & M-2W & M-3 & LA-BKG \\
\hline Juveniles & & & & \\
\hline Non-Scrotal & 0 & 0 & 0 & 0 \\
\hline Scrotal & 2 & 9 & 0 & 0 \\
\hline \multicolumn{1}{|c|}{ Females } & 0 & 4 & 0 & 0 \\
\hline Juveniles & 0 & 0 & 0 & 0 \\
\hline Lactating & 0 & 1 & 0 & 0 \\
\hline $\begin{array}{l}\text { Non-reproductive } \\
\text { (adults) }\end{array}$ & 4 & 13 & 0 & 0 \\
\hline Pregnant & 0 & 5 & 0 & 0 \\
\hline
\end{tabular}


Table 3. Number of male and female deer mice captured during the summer in all four sampling areas.

\begin{tabular}{|l|c|c|c|c|}
\hline \multicolumn{1}{|c|}{ Males } & E-1W & M-2W & M-3 & LA-BKG \\
\hline Juveniles & & & & \\
\hline Non-Scrotal Females & 0 & 0 & 1 & 0 \\
\hline Scrotal & 1 & 2 & 9 & 8 \\
\hline \multicolumn{1}{|c|}{ Juveniles } & 4 & 2 & 3 & 2 \\
\hline Lactating & & & & \\
\hline Non-reproductive (adults) & 0 & 0 & 0 & 0 \\
\hline Pregnant & 5 & 1 & 3 & 1 \\
\hline
\end{tabular}

\section{Male Deer Mice}

Non-scrotal males were captured in all four sampling locations, E-1W $(n=1), M-2 W(n=2), M-$ $3(\mathrm{n}=9)$, and LA-BKG $(\mathrm{n}=8)$. Scrotal males were also captured in all four locations, E-1W $(\mathrm{n}=4), M-2 \mathrm{~W}(\mathrm{n}=2), \mathrm{M}-3(\mathrm{n}=3)$, and LA-BKG $(\mathrm{n}=2)$. One juvenile male was collected in M-3 (Table 3 and Figure 17).

\section{Female Pinyon Mice}

One lactating female pinyon mouse was captured in M-2W. Non-reproductive female pinyon mice were captured in E-1W ( $=1), M-2 W(n=5)$, and LA-BKG $(n=1)$. One pregnant female pinyon mouse was captured in LA-BKG. No female pinyon mice were captured in $\mathrm{M}-2 \mathrm{~W}$ or $\mathrm{M}-3$ (Table 4 and Figure 18).

\section{Male Pinyon Mice}

Male pinyon mice were not captured at any of the sampling locations (Table 4).

\section{Female Western Harvest Mice}

One non-reproductive and one pregnant female western harvest mouse were captured in M-3. Western harvest mice were not captured in any of the remaining three sampling locations (Table 5 and Figure 19). 


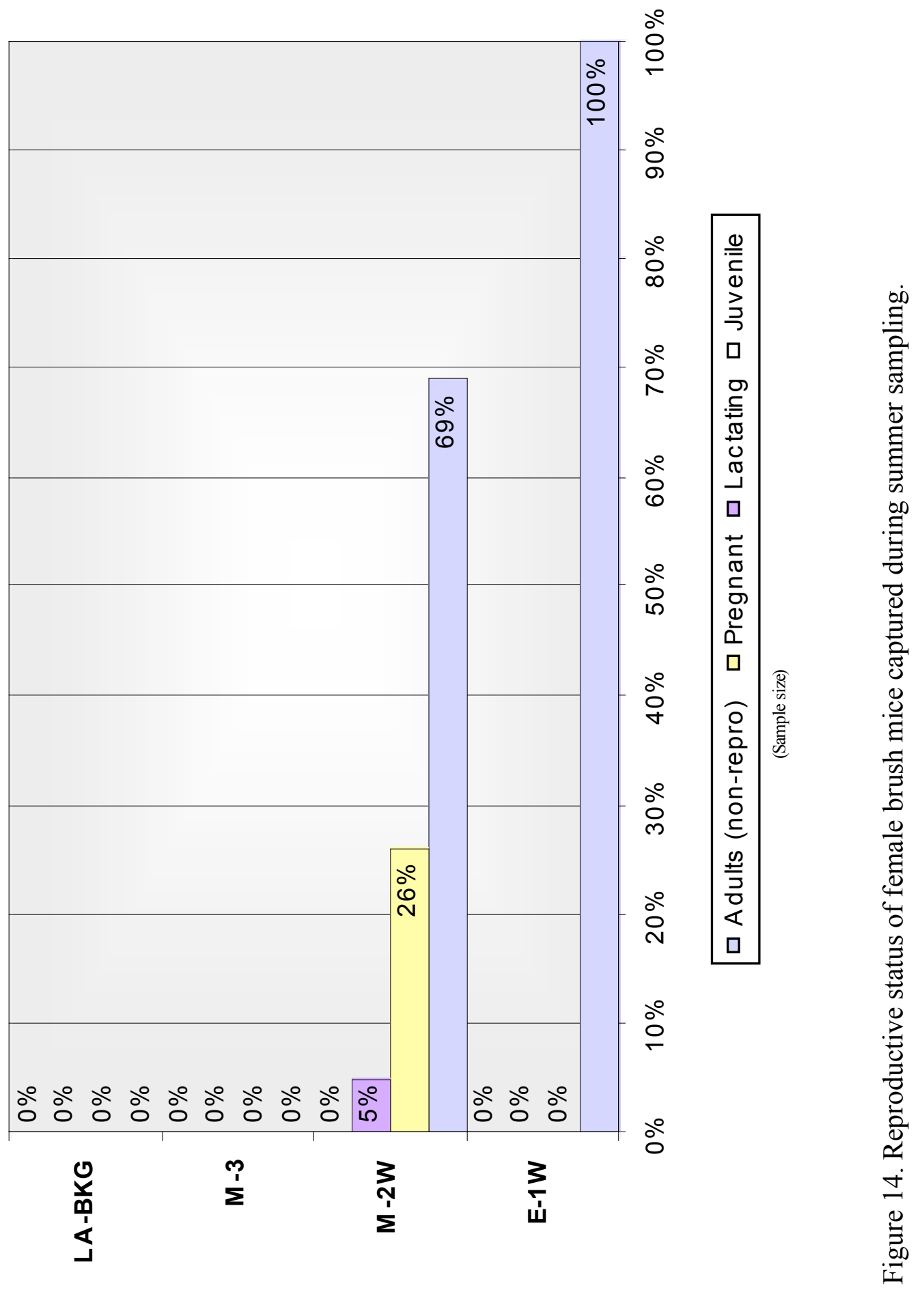




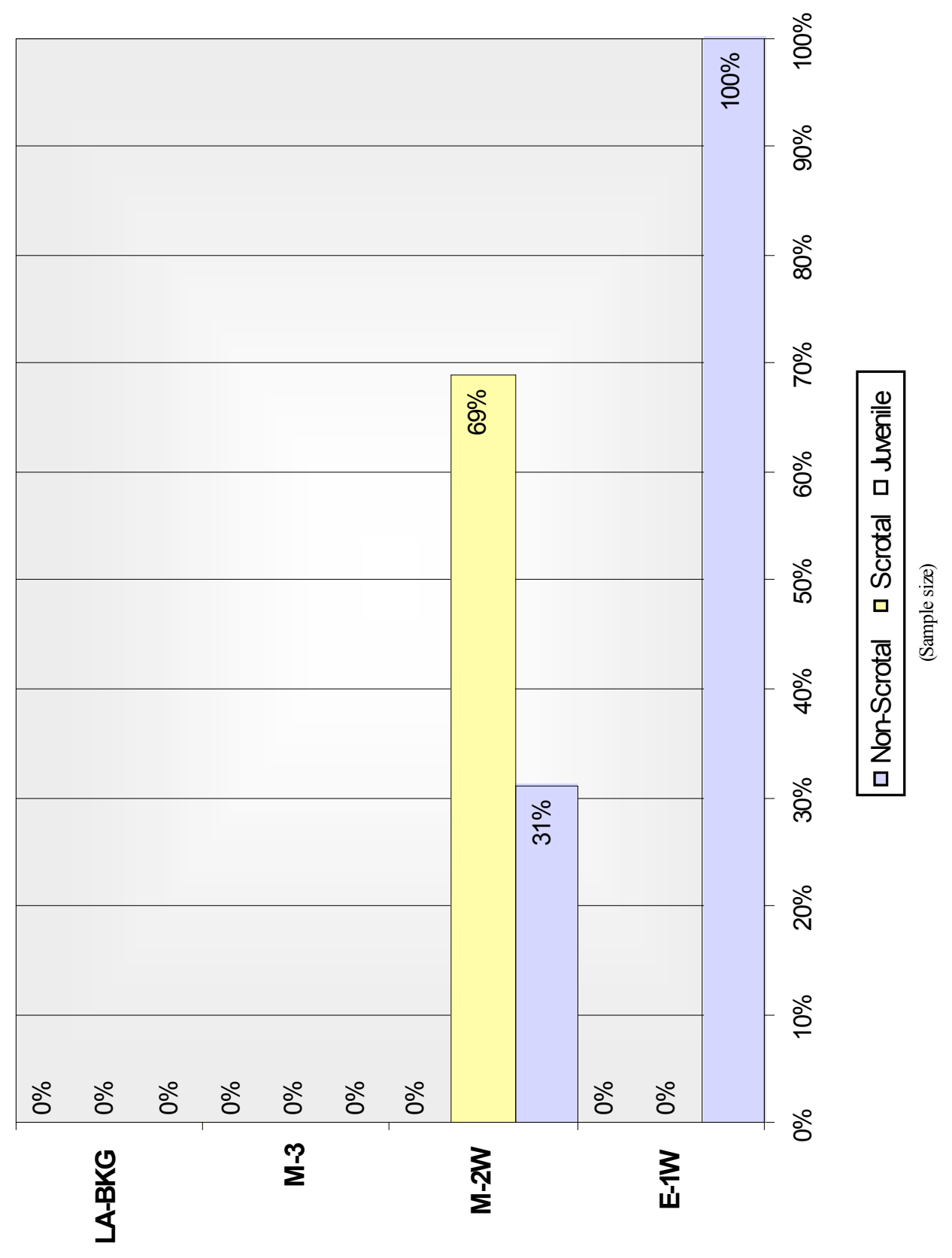

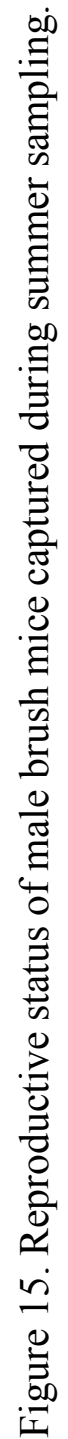




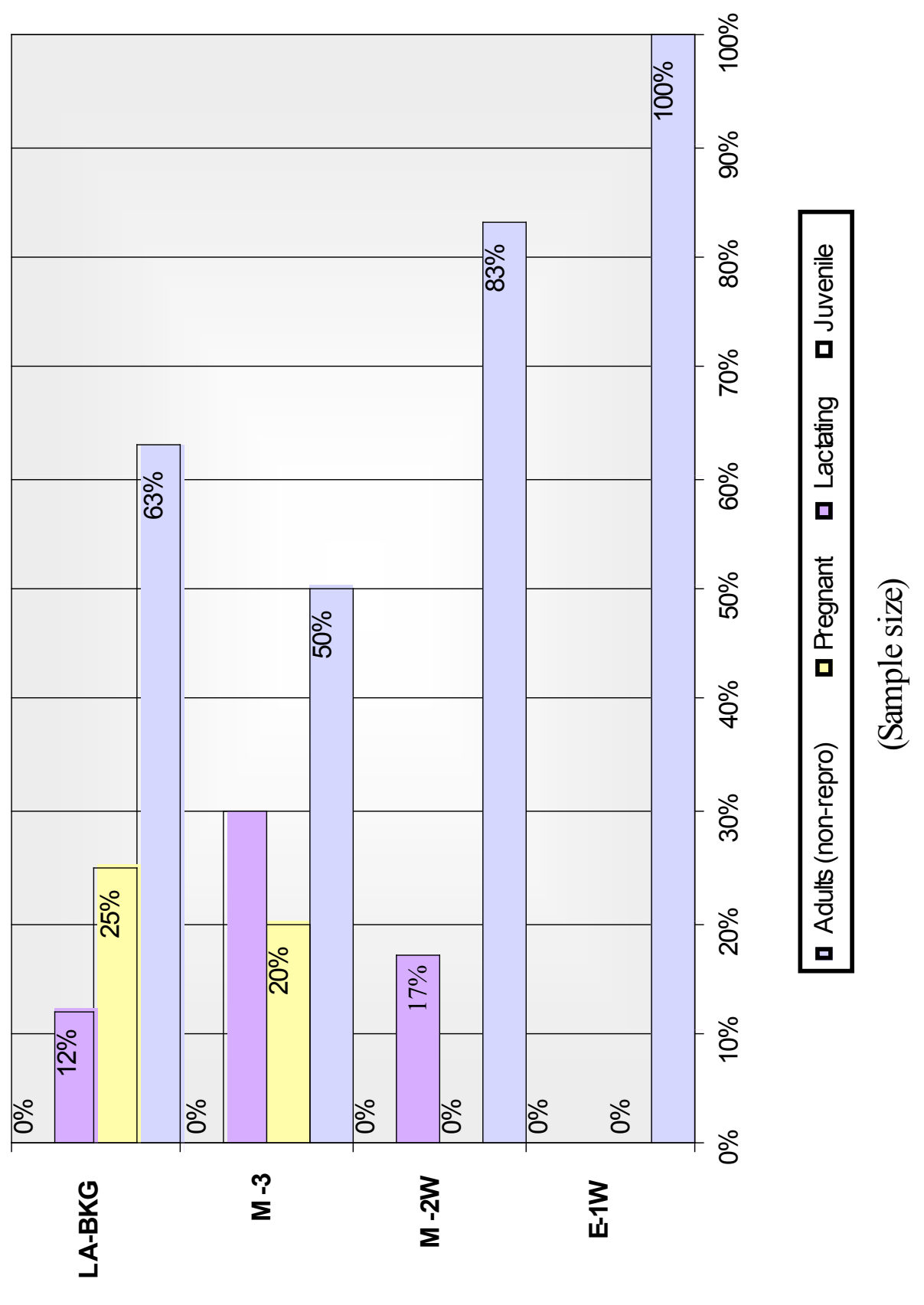

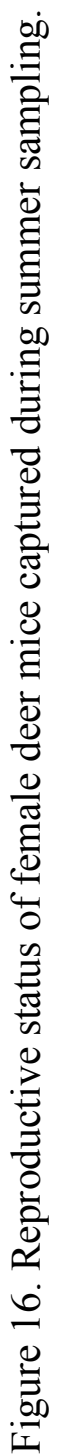




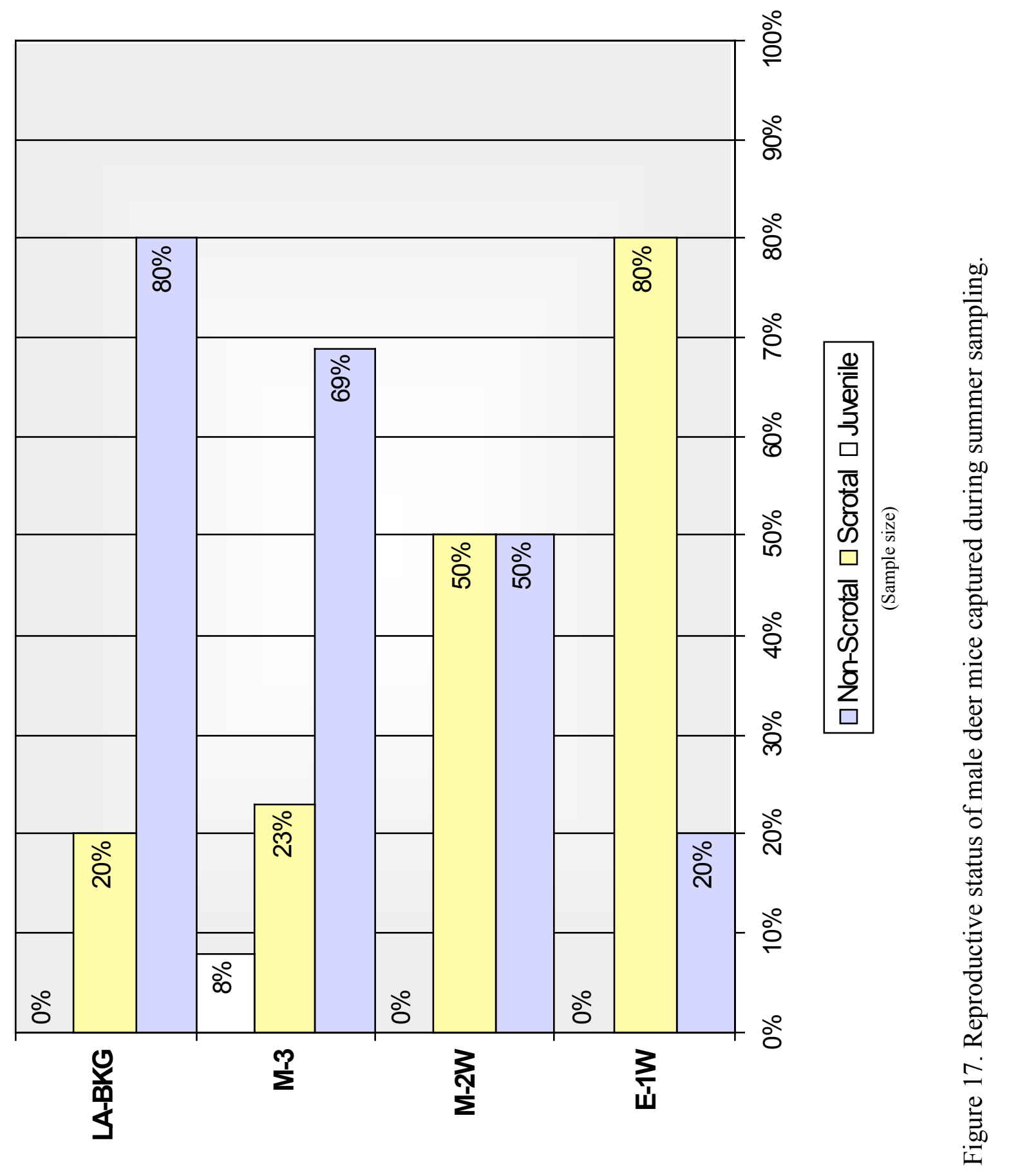


Table 4. Number of male and female pinyon mice captured during the summer in all four sampling areas.

\begin{tabular}{|l|c|c|c|c|}
\hline \multicolumn{1}{|c|}{ Males } & E-1W & M-2W & M-3 & LA-BKG \\
\hline Juveniles & & & & \\
\hline Non-Scrotal & 0 & 0 & 0 & 0 \\
\hline Scrotal Females & 0 & 0 & 0 & 0 \\
\hline \multicolumn{1}{|c|}{} & 0 & 0 & 0 & 0 \\
\hline Juveniles & & & & \\
\hline Lactating & 0 & 0 & 0 & 0 \\
\hline Non-reproductive (adults) & 1 & 0 & 0 & 0 \\
\hline Pregnant & 0 & 0 & 0 & 1 \\
\hline
\end{tabular}

Table 5. Number of male and female western harvest mice captured during the summer in all four sampling areas.

\begin{tabular}{|l|c|c|c|c|}
\hline \multicolumn{1}{|c|}{ Males } & E-1W & M-2W & M-3 & LA-BKG \\
\hline Juveniles & & & & \\
\hline Non-Scrotal Females & 0 & 0 & 1 & 0 \\
\hline Scrotal & 0 & 0 & 2 & 0 \\
\hline & 1 & 0 & 5 & 0 \\
\hline Juveniles & & & & \\
\hline Lactating & 0 & 0 & 0 & 0 \\
\hline Non-reproductive (adults) & 0 & 0 & 0 & 0 \\
\hline Pregnant & 0 & 0 & 1 & 0 \\
\hline
\end{tabular}



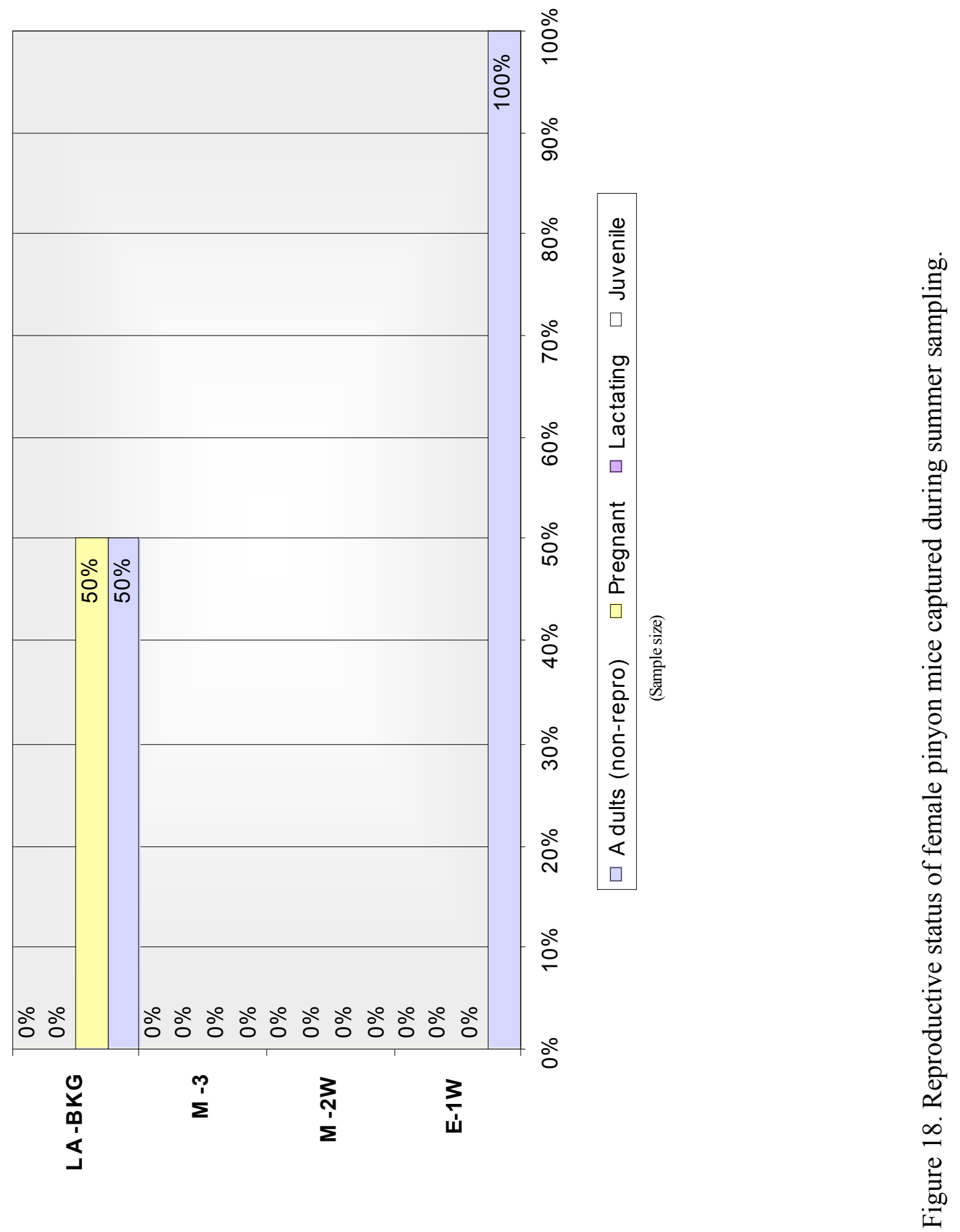


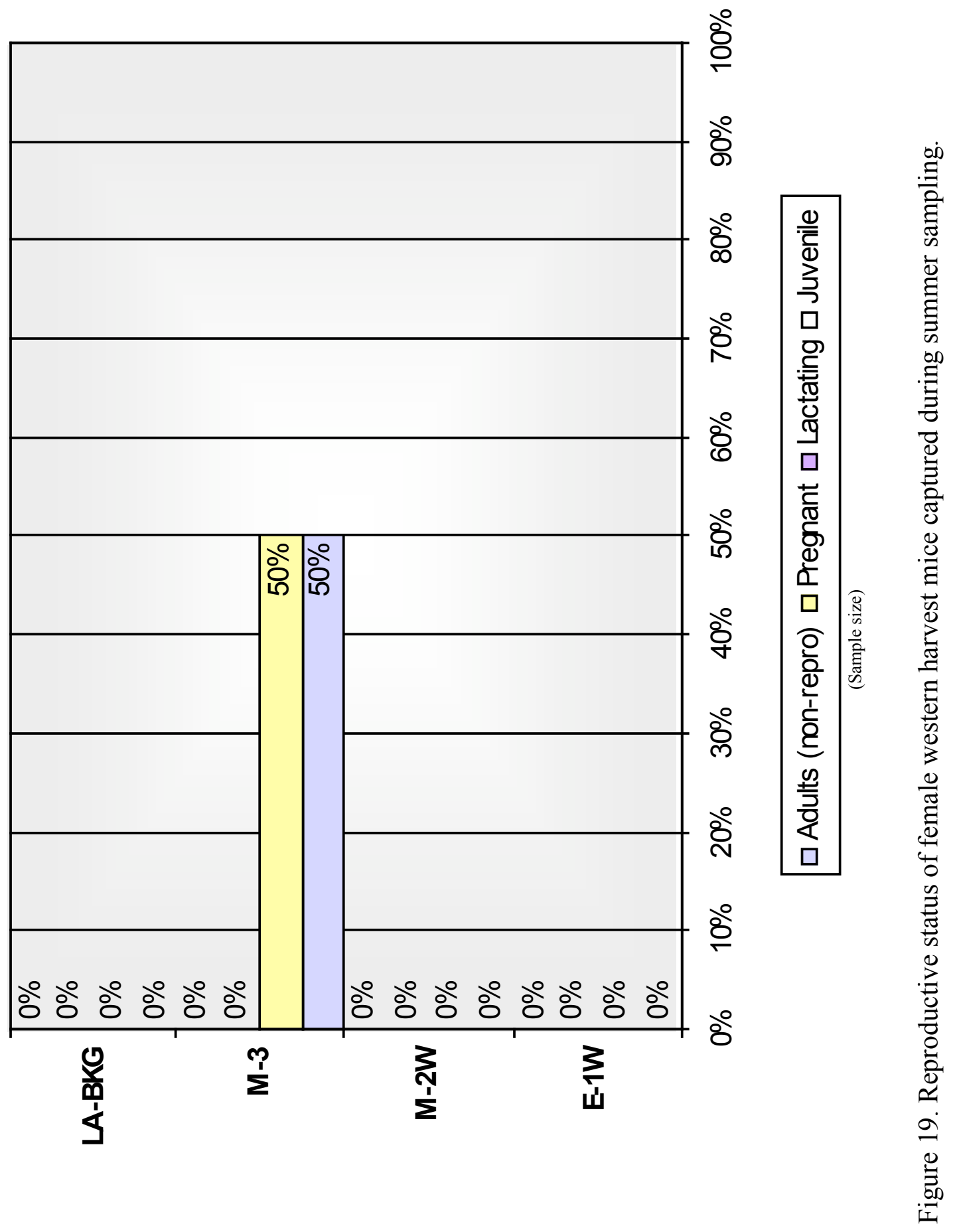




\section{Male Western Harvest Mice}

Juvenile ( $\mathrm{n}=1)$, non-scrotal $(\mathrm{n}=2)$, and scrotal $(\mathrm{n}=5)$ male western harvest mice were captured in M-3. One scrotal male western harvest mouse was captured in E-1W and none were captured in the remaining two sampling locations (M-2W and LA-BKG) (Table 5 and Figure 20).

\section{Female Mexican Wood Rats}

Female Mexican wood rats were captured in two of the four sampling locations. Lactating $(\mathrm{n}=1)$, non-reproductive $(\mathrm{n}=2)$, and pregnant $(\mathrm{n}=2)$ female wood rats were captured in M- $2 \mathrm{~W}$. Only one lactating female wood rat was captured in E-1W (Table 6 and Figure 21).

\section{Male Mexican Wood Rats}

Male Mexican wood rats were captured in every location except LA-BKG. Non-scrotal males were captured in E-1W $(n=1), M-2 W(n=8)$, and M-3 $(n=4)$. Scrotal males were captured in M-2W $(\mathrm{n}=1)$ and M-3 $(\mathrm{n}=1)$ (Table 6 and Figure 22).

Table 6. Number of male and female Mexican wood rats captured during the summer in all four sampling areas.

\begin{tabular}{|l|c|c|c|c|}
\hline \multicolumn{1}{|c|}{ Males } & E-1W & M-2W & M-3 & LA-BKG \\
\hline Juveniles & & & & \\
\hline Non-Scrotal Females & 0 & 0 & 0 & 0 \\
\hline Scrotal & 1 & 8 & 4 & 0 \\
\hline \multicolumn{1}{|c|}{ Fuveniles } & 0 & 1 & 1 & 0 \\
\hline Lactating & 0 & 0 & 0 & 0 \\
\hline Non-reproductive (adults) & 1 & 1 & 0 & 0 \\
\hline Pregnant & 0 & 2 & 0 & 0 \\
\hline
\end{tabular}




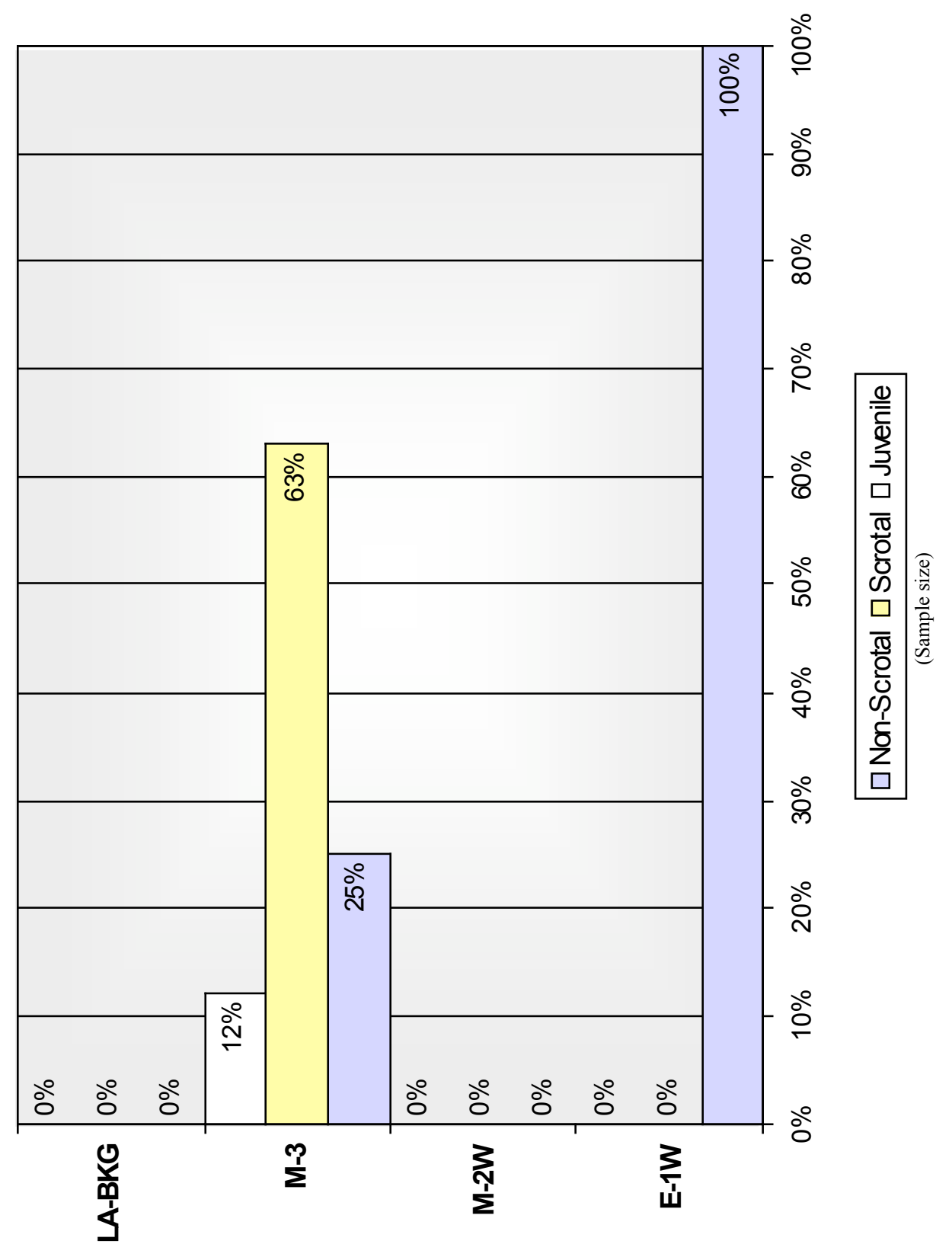

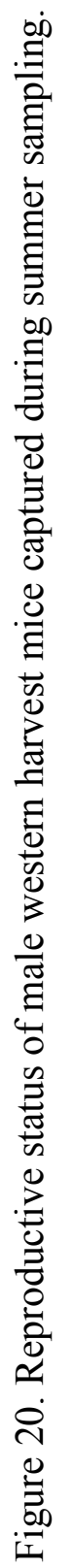




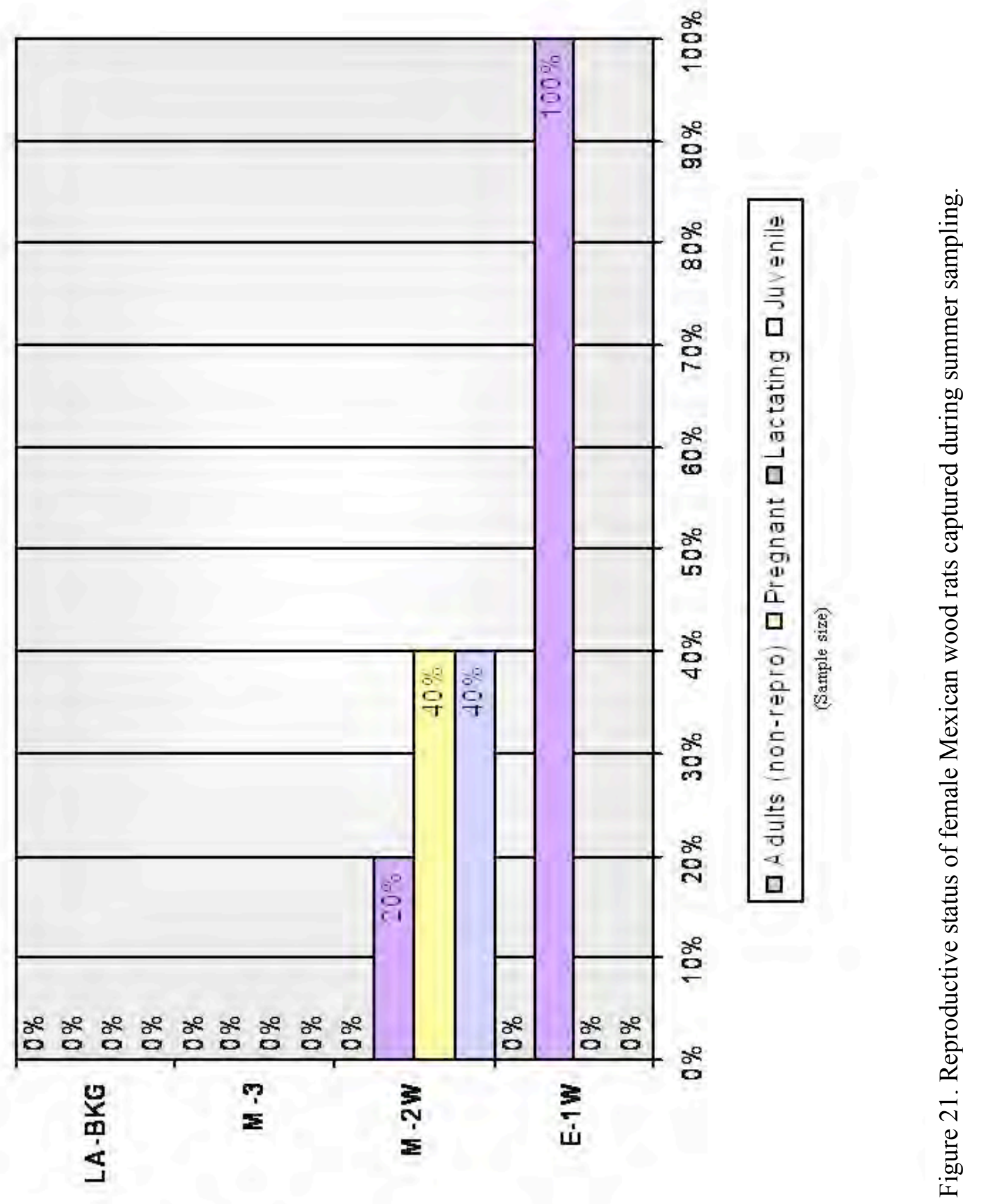




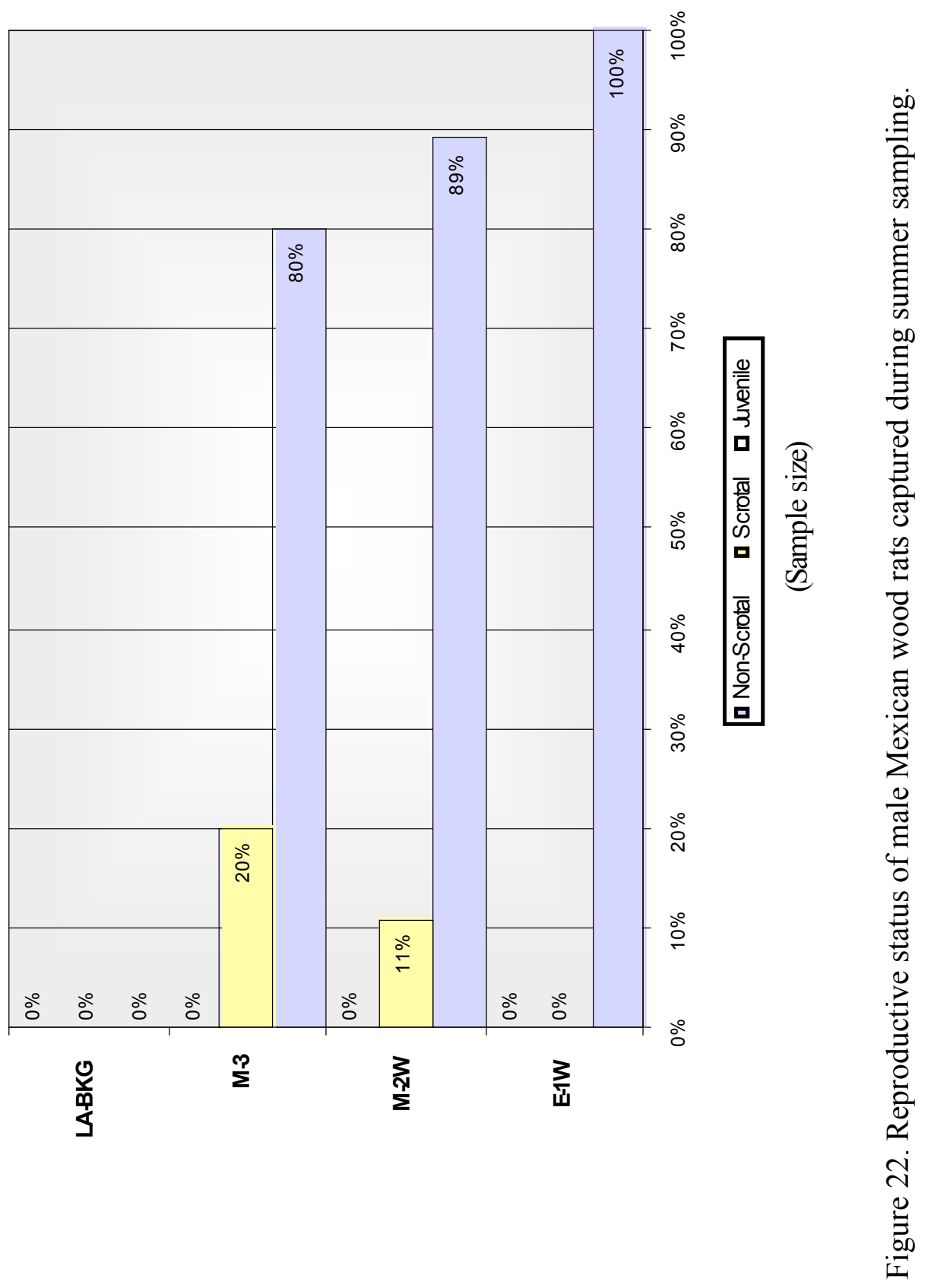




\section{Female Long-tailed Voles}

One non-reproductive female was captured in LA-BKG. Female long-tailed voles were not captured in E-1W, M-2W, or M-3 (Table 7 and Figure 23).

\section{Male Long-tailed Voles}

Male long-tailed voles were present in two of the four sampling locations. Non-scrotal males were captured in E-1W $(n=1)$ and LA-BKG $(n=2)$. Scrotal males were also captured in E-1W $(\mathrm{n}=1)$ and LA-BKG $(\mathrm{n}=2)$ (Table 7 and Figure 24).

Female Vagrant Shrews

Only one reproductive category of female vagrant shrews was represented in two of the four sampling locations. Non-reproductive female vagrant shrews were captured in E-1W $(n=2)$ and LA-BKG $(\mathrm{n}=1)$ (Table 8 and Figure 25).

\section{Male Vagrant Shrews}

Male vagrant shrews were not captured in any of the four sampling locations (Table 8).

Table 7. Number of male and female long-tailed voles captured during the summer in all four sampling areas.

\begin{tabular}{|c|c|c|c|c|}
\hline & E-1W & M-2W & M-3 & LA-BKG \\
\hline \multicolumn{5}{|l|}{ Males } \\
\hline Juveniles & 0 & 0 & 0 & 0 \\
\hline Non-Scrotal & 1 & 0 & 0 & 2 \\
\hline Scrotal & 1 & 0 & 0 & 2 \\
\hline \multicolumn{5}{|c|}{ Females } \\
\hline Juveniles & 0 & 0 & 0 & 0 \\
\hline Lactating & 0 & 0 & 0 & 0 \\
\hline Non-reproductive (adults) & 0 & 0 & 0 & 1 \\
\hline Pregnant & 0 & 0 & 0 & 0 \\
\hline
\end{tabular}


Table 8. Number of male and female vagrant shrews captured during the summer in all four sampling areas.

\begin{tabular}{|l|c|c|c|c|}
\hline \multicolumn{1}{|c|}{ Males } & E-1W & M-2W & M-3 & LA-BKG \\
\hline Juveniles & & & & \\
\hline Non-Scrotal & 0 & 0 & 0 & 0 \\
\hline Scrotal Females & 0 & 0 & 0 & 0 \\
\hline \multicolumn{1}{|c|}{} & 0 & 0 & 0 & 0 \\
\hline Juveniles & 0 & 0 & 0 & 0 \\
\hline Lactating & 0 & 0 & 0 & 0 \\
\hline Non-reproductive (adults) & 2 & 0 & 0 & 1 \\
\hline Pregnant & 0 & 0 & 0 & 0 \\
\hline
\end{tabular}

\section{Body Weights}

Body weights were compared for adult deer mice by sex between the four trapping sites. Deer mice were the only species with sufficient sample sizes to be compared across all four sites (Figures 26 and 27). However, there was sufficient sample size to compare adult body weights of male wood rats between $\mathrm{M}-2 \mathrm{~W}$ and $\mathrm{M}-3$ using a $t$-Test.

\section{Female Deer Mouse}

The weights of adult female deer mice were compared across all four sites. There was no significant difference detected between sites ( $G L M, F=1.465, p=0.2479)$. Mean weights ranged from $15.4 \mathrm{~g}(\mathrm{E}-1 \mathrm{~W})$ to $19.5 \mathrm{~g}(\mathrm{M}-3)$.

\section{Male Deer Mouse}

The weights of adult male deer mice were compared across all four sites. There was no significant difference detected between sites (GLM, $F=0.6821, p=0.5710)$. Mean weights ranged from $14.6 \mathrm{~g}(\mathrm{LA}-\mathrm{BKG})$ to $17.1 \mathrm{~g}(\mathrm{E}-1 \mathrm{~W})$.

\section{Male Mexican Wood Rat}

The weights of adult male wood rats were compared between sites M-2W and M-3. There was no significant difference in weights detected between the sites $(t$-Test, $t=0.3630, \mathrm{p}=0.7234)$. The mean adult weight at M-2W was $123.7 \mathrm{~g}$ and the mean weight at M-3 was $112.5 \mathrm{~g}$. 


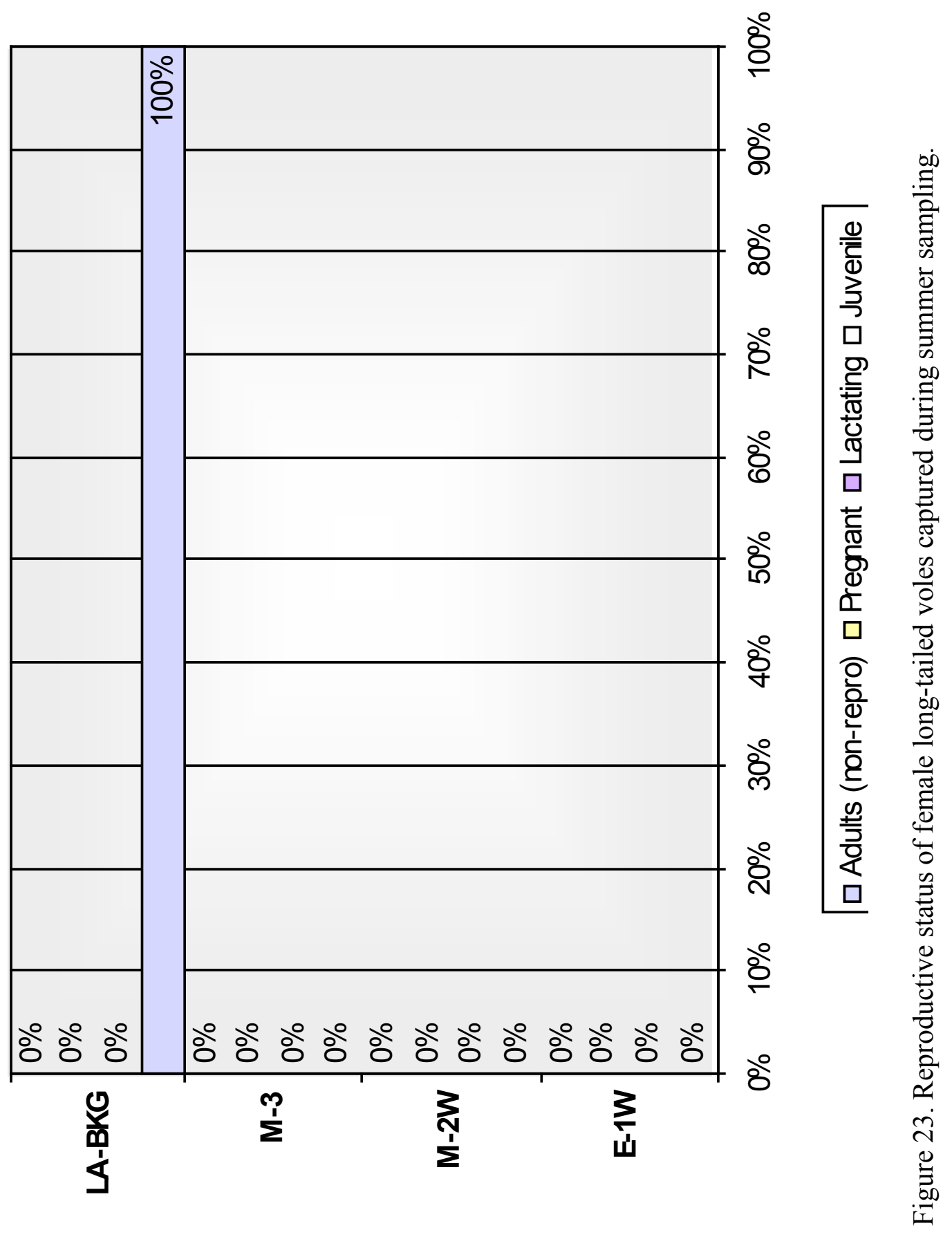




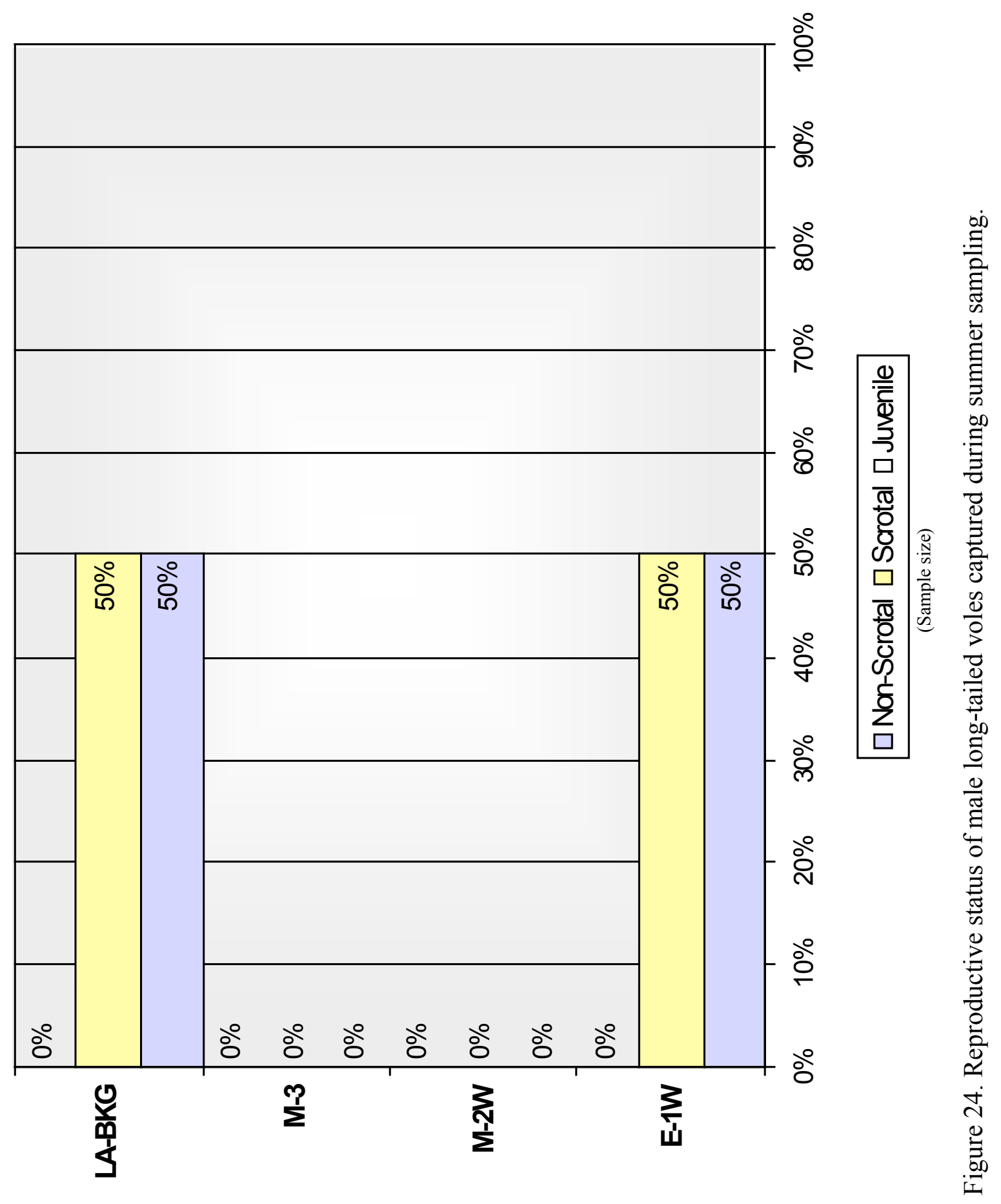




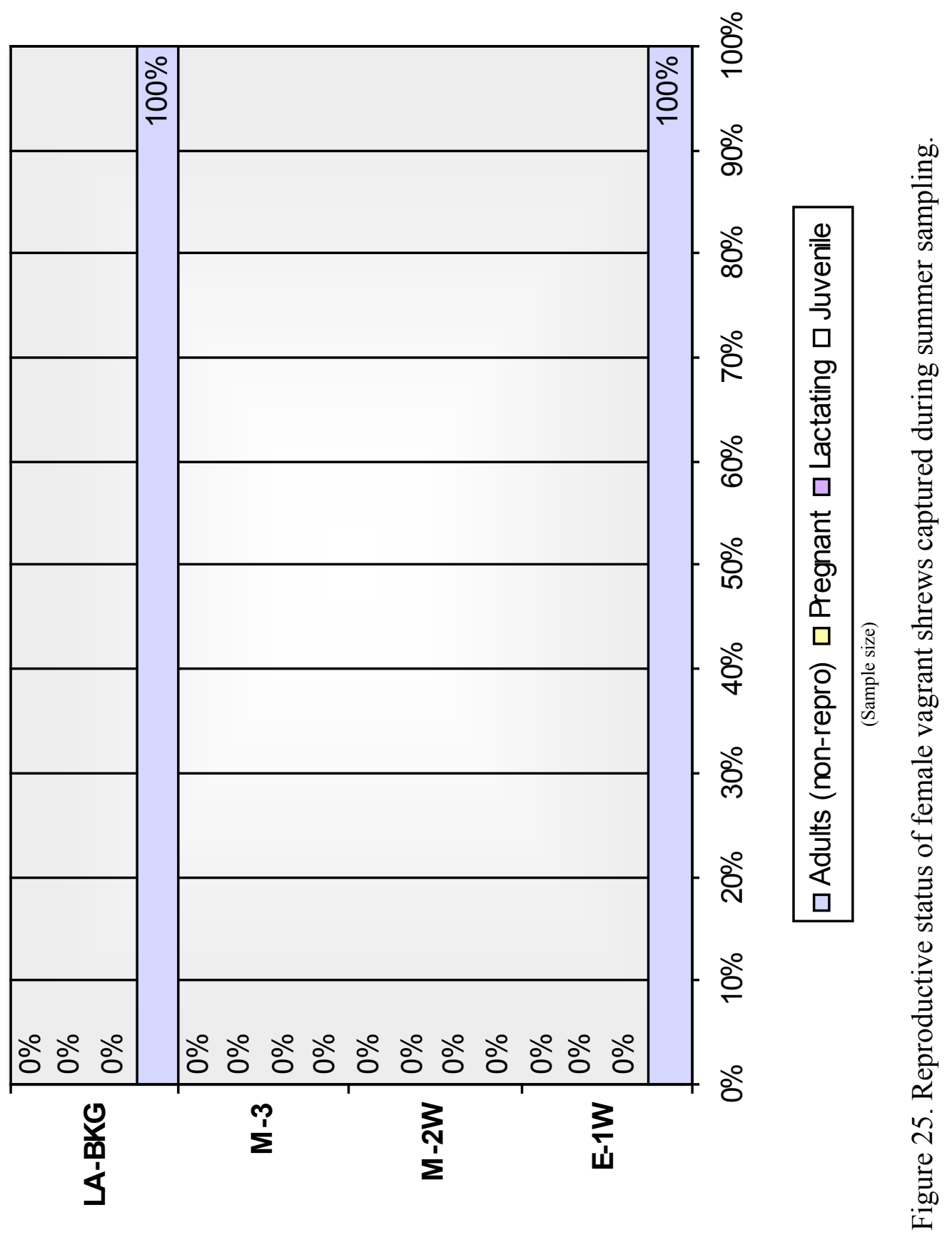



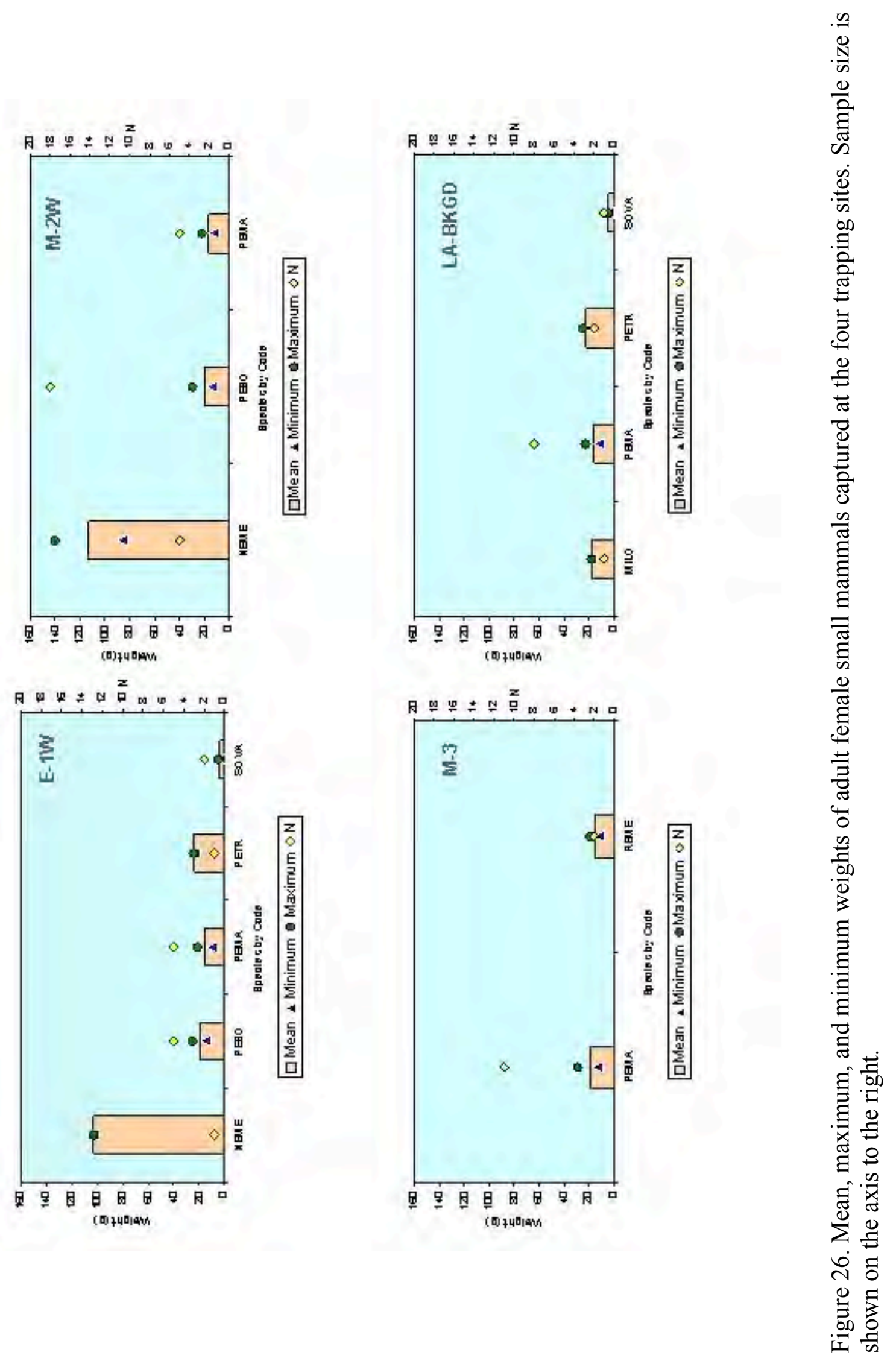

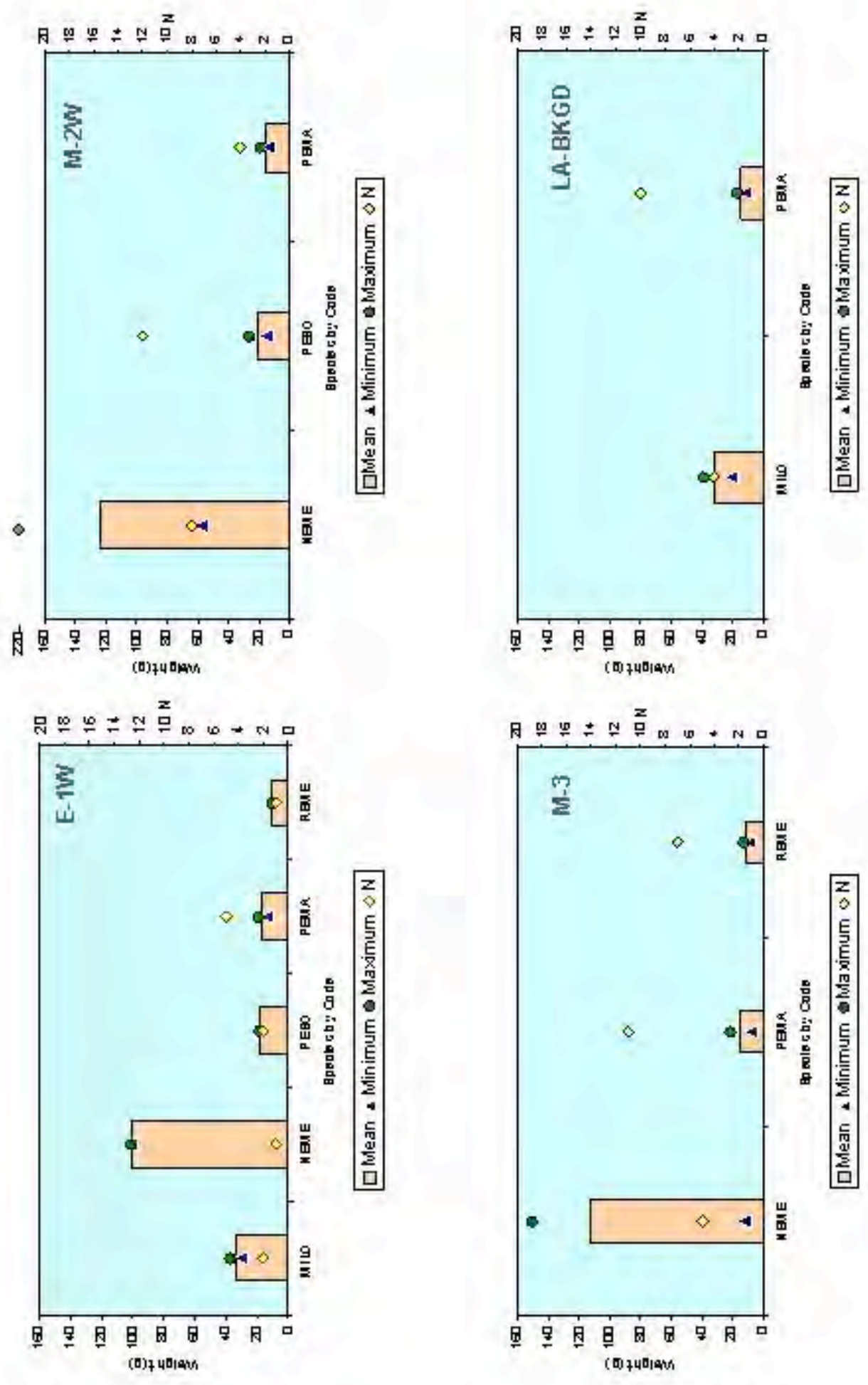

$\frac{n}{\sqrt[N]{2}}$

言

$\cdot \frac{\dot{\mathscr{D}}}{\omega}$

b

त्ञ

亏

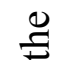

후

고

吾

:

常

ีㅡㄹ

ㄹ.

$\Xi$

可

荧

号

छั

吾急

पू

$\stackrel{0}{\Xi}$

.00

ए

$\Xi$

苯

.

当

르

छ.

范

छ

ఏ્ฮ

里

สี

$\sum \stackrel{0}{\Xi}$

ปิ

농

步 $\frac{0}{\infty}$ 


\section{SUMMARY AND DISCUSSION}

This investigation was initiated as a means for determining potential adverse effects to small mammal populations within the Mortandad watershed that could be attributed to the COPECs in the terrestrial and riparian systems. Differences were found in species composition, diversity, sex composition, and reproductive status at the four trapping locations. This report summarizes the results of the sampling period.

Of the three reaches in Mortandad, E-1W had the highest diversity index (2.25). All seven species of interest were captured in E-1W. The reference site, LA-BKG, had the lowest diversity index (1.267).

Diversity indices for M-2W and M-3 were slightly greater than LA-BKG.

Species composition varied widely among the three reaches in Mortandad (E-1W, M-2W, M-3) and LA-BKG. Deer mice were the only species common among all of the sampling locations. The greatest overlap in species composition occurred between E-1W and LA-BKG. Pinyon mice, shrews, and voles were captured in small numbers in both locations. Differences in species composition are most likely a result of differences in habitat among the trapping locations. Reach M-3 is located in a fairly wide canyon, dominated by a grass understory and oak/ponderosa pine overstory, and lacked the presence of surface water during the trapping period. Reach $\mathrm{M}-2 \mathrm{~W}$ is located in a narrow canyon with intermittent pools scattered throughout. Reach E-1W is located at a slightly higher elevation and is characterized by wetland vegetation. It received effluent discharge during the trapping period. The trapping location in LA-BKG was located in the upper portion of the canyon and is characterized by a riparian understory and ponderosa pine/mixed conifer overstory. The stream channel, which runs through the trapping location, was actively flowing during the sampling period. Elevation differences among the four sampling locations, however slight in some instances, directly influences the vegetation type and therefore, impacts the small mammal species present.

In general, body weights of adult small mammal species were similar for all four sampling locations. Body weights of deer mice, both male and female, were compared across all four sites and weights of male Mexican wood rats were compared between M-2W and M-3. Other species could not be compared due to insufficient sample sizes. No significant differences were detected 
between sexes or sites. Minor variations could be attributed to food source availability and competition.

General reproductive status of the three reaches and background site varied greatly with the exception of non-reproductive female, scrotal, and non-scrotal male deer mice, which were captured in all four sampling locations. The differences in reproductive classes could be the result of low capture rates and/or environmental pressures such as drought. There were no statistical differences found between the sex ratios of male and female small mammals that were analyzed.

Capture rates for all four sampling locations were low and resulted in low density estimates for each area sampled.

E-1W had the highest mean capture rate (21.67\%) and LA-BKG had the lowest (6.75\%). Capture rates decreased with the downstream gradient (M-2W and M-3). Drought-like conditions have prevailed in Los Alamos County for the past 8 to 10 years. This trend remains constant due to the lack of snowfall during the winter of 2005-2006 and may have had the most significant impact on sampling success.

\section{ACKNOWLEDGMENTS}

We would like to thank Danny Katzman, Kirby Olson, Steven Reneau, and Randy Ryti of the Canyons Investigation Team of the Environmental Remediation and Surveillance Program for preparing the study plan, providing funding for the project, and reviewing this document. We would like to thank field crewmembers Marwin Shendo, Guillermo Vigil, and Aaron Lenihan for their assistance. In addition to the field crew, we would also like to thank Gil Gonzales, Leslie Hansen, and Dave Keller for their participation in reviewing and commenting on the project plan. We also thank Hector Hinojosa for his assistance in the review and final preparation of the manuscript. 


\section{REFERENCES}

Balice, R.G. and L.F. Sandoval. 2006. "Mortandad Canyon: Plant Survey 2005." Los Alamos National Laboratory report LA-UR-06-0390.

Beitinger, T.L. 1988. Biostatistics Helpbook. University of North Texas, Denton, Texas.

Bennett, K.D., J.R. Biggs, and P.R. Fresquez. 1996. "Contaminant Monitoring of Biota Downstream of a Radioactive Liquid Waste Treatment Facility, Los Alamos National Laboratory." Proceedings of the HSRC/WERC Joint Conference on the Environment.

Gallaher, B.M., D.W. Efurd, D.J. Rokop, T.M. Benjamin, and A.K. Stoker. 1997. "Survey of Plutonium and Uranium Atom Ratios and Activity Levels in Mortandad Canyon." Los Alamos National Laboratory report LA-13379-MS.

LANL (Los Alamos National Laboratory). 2000. "Spatial Database of Orthophotography of Pajarito Plateau." compiled by Bill Carey and Greg Cole, Los Alamos National Laboratory.

LANL (Los Alamos National Laboratory). 2003. "Phase III RFI Report for Solid Waste Management Unit 16-021(c)-99.” Los Alamos National Laboratory document LA-UR-03-5248.

LANL (Los Alamos National Laboratory). 2004. "Los Alamos and Pueblo Canyons Investigation Report." Los Alamos National Laboratory document LA-UR-04-8246.

LANL (Los Alamos National Laboratory). 2005. "Mortandad Canyon Biota Investigation Work Plan.” Los Alamos National Laboratory document LA-UR-05-2231.

Hair, J.D. 1980. "Measurement of Ecological Diversity." In Wildlife Management Techniques Manual, S.D. Schemnitz, ed., $4^{\text {th }}$ Ed., revised (The Wildlife Society).

Robinson, R.J. and K.D. Bennett. 2002. "Summer and Fall Small Mammal Sampling in Pueblo, Guaje, Acid, and Los Alamos Canyons." Los Alamos National Laboratory report LA-14047.

SAS Institute, Inc. 1988. SAS/STAT User's Guide. SAS Institute, Inc., Cary, North Carolina.

Talmage, S.S. 1989. “Comparative Evaluation of Several Small Mammal Species as Monitors of Heavy Metals, Radionuclides, and Selected Organic Compounds in the Environment." Dissertation. University of Michigan, Ann Arbor.

Zar, J.H. 1984. Biostatistical Analysis. Prentice-Hall, Inc., Englewood Cliffs, New Jersey. 

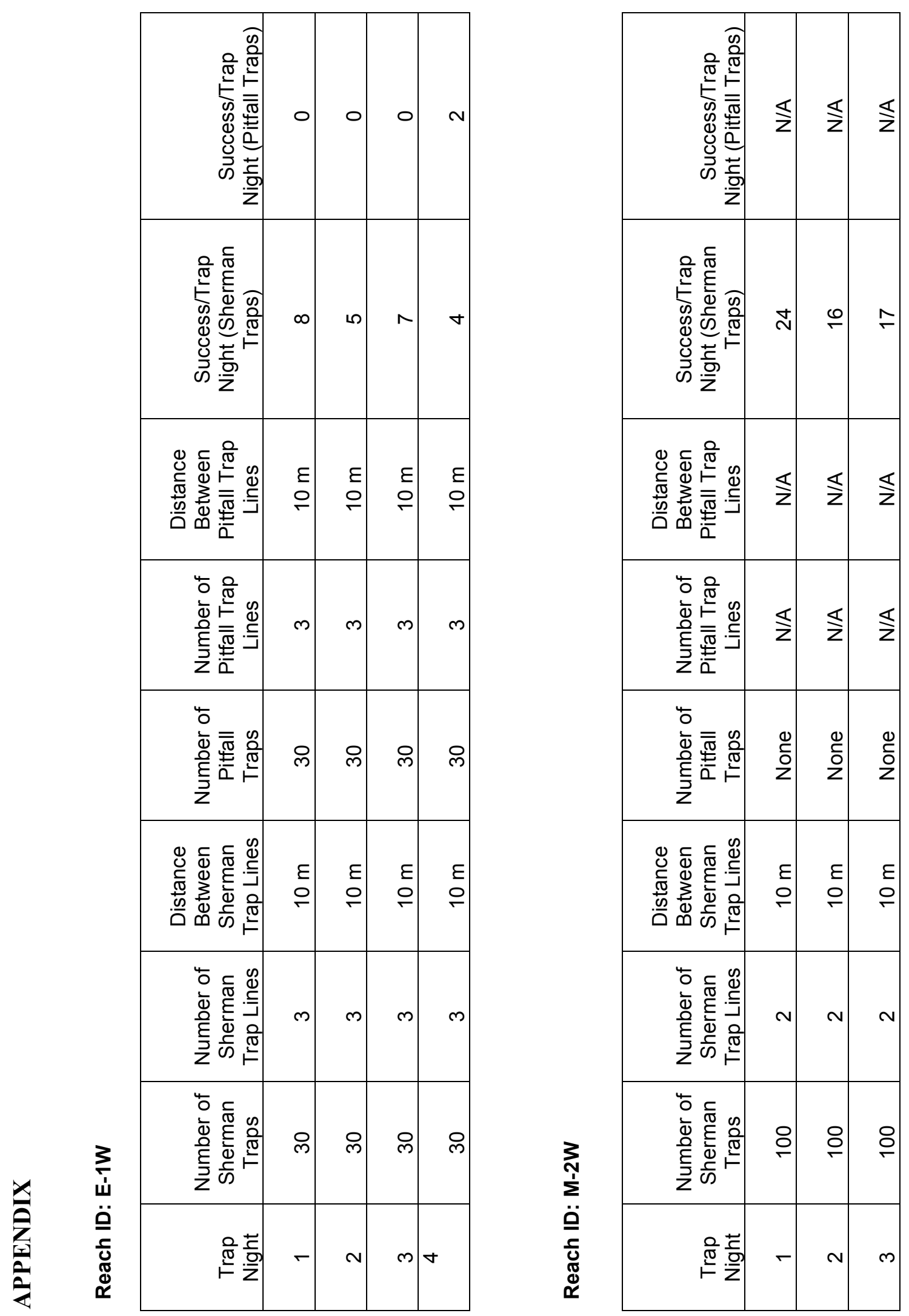


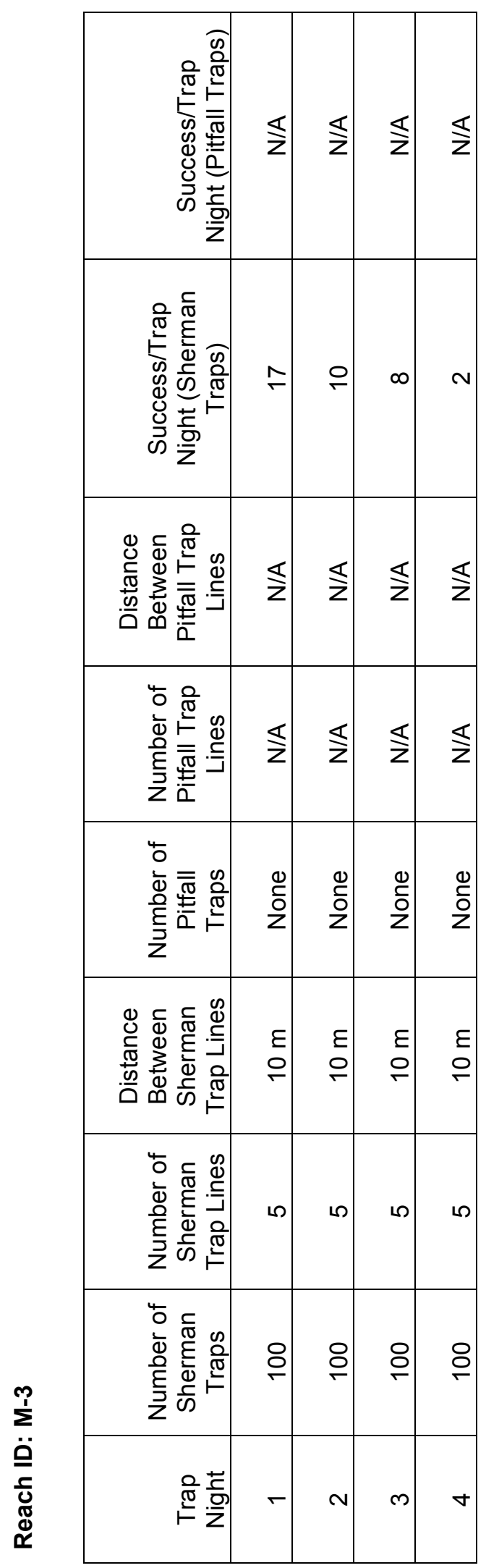

\begin{tabular}{|c|c|c|c|c|}
\hline 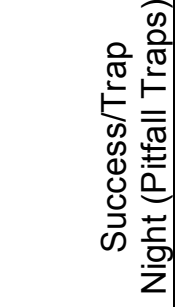 & 0 & 0 & - & 0 \\
\hline 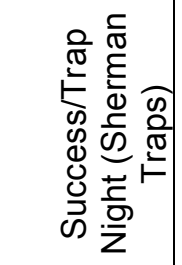 & $\check{\tau}$ & $\infty$ & 10 & $r$ \\
\hline 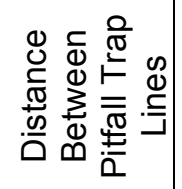 & $\begin{array}{l}\varepsilon \\
\text { \& }\end{array}$ & $\begin{array}{l}\varepsilon \\
O \\
O\end{array}$ & $\begin{array}{l}\varepsilon \\
o \\
\dot{q}\end{array}$ & $\begin{array}{l}\varepsilon \\
\text { \& }\end{array}$ \\
\hline 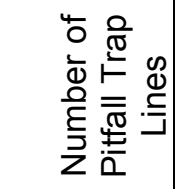 & $N$ & $N$ & $N$ & $N$ \\
\hline 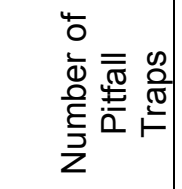 & $\stackrel{2}{2}$ & $\stackrel{20}{\square}$ & $\stackrel{20}{\sim}$ & $\stackrel{10}{2}$ \\
\hline 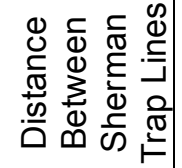 & $\begin{array}{l}\varepsilon \\
\end{array}$ & $\begin{array}{l}\varepsilon \\
0 \\
\circ\end{array}$ & $\begin{array}{l}\varepsilon \\
\stackrel{\varepsilon}{-}\end{array}$ & $\begin{array}{l}\varepsilon \\
\circ \\
\circ\end{array}$ \\
\hline 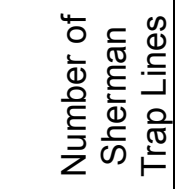 & م & 10 & 10 & 10 \\
\hline 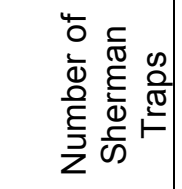 & 음 & 음 & $\stackrel{8}{\circ}$ & 웅 \\
\hline 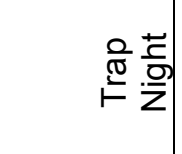 & $r$ & $N$ & $m$ & $\nabla$ \\
\hline
\end{tabular}


This report has been reproduced directly from the best available copy. It is available electronically on the Web (http://www.doe.gov/bridge).

Copies are available for sale to U.S. Department of Energy employees and contractors from:

Office of Scientific and Technical Information

P.O. Box 62

Oak Ridge, TN 37831

(865) 576-8401

Copies are available for sale to the public from: National Technical Information Service

U.S. Department of Commerce

5285 Port Royal Road

Springfield, VA 22161

(800) 553-6847 
- Los Alamos NATIONAL LABORATORY

EST.1943 